\title{
G-protein Coupled Receptor Signaling in Pluripotent Stem Cell-derived Cardiovascular Cells: Implications for Disease Modeling
}

\author{
Nazanin F. Dolatshad ${ }^{1+}$, Nicola Hellen ${ }^{1 \dagger}$, Richard J. Jabbour ${ }^{1 \dagger}$, Sian E. Harding ${ }^{1 *}$ and \\ Gabor Földes ${ }^{1,2}$
}

${ }^{1}$ Myocardial Function, National Heart and Lung Institute, Imperial College London, London, UK, ${ }^{2}$ The Heart and Vascular Center of Semmelweis University, Semme/weis University, Budapest, Hungary

\section{OPEN ACCESS}

Edited by:

Cedric Viero,

Saarland University Medical Center,

Germany

Reviewed by:

Julien Hanson,

University of Liège, Belgium

Beklem Bostancioglu,

Karolinska Institute, Sweden

Karl Erik Akerman,

University of Helsinki, Finland

*Correspondence:

Sian E. Harding

sian.harding@imperial.ac.uk

${ }^{\dagger}$ These authors have contributed equally to this work.

Specialty section

This article was submitted to

Stem Cell Treatments,

a section of the journal

Frontiers in Cell and Developmental

Biology

Received: 24 May 2015 Accepted: 09 November 2015 Published: 09 December 2015

Citation:

Dolatshad NF, Hellen N, Jabbour RJ, Harding SE and Földes G (2015) G-protein Coupled Receptor Signaling

in Pluripotent Stem Cell-derived Cardiovascular Cells: Implications for

Disease Modeling.

Front. Cell Dev. Biol. 3:76. doi: 10.3389/fcell.2015.00076
Human pluripotent stem cell derivatives show promise as an in vitro platform to study a range of human cardiovascular diseases. A better understanding of the biology of stem cells and their cardiovascular derivatives will help to understand the strengths and limitations of this new model system. G-protein coupled receptors (GPCRs) are key regulators of stem cell maintenance and differentiation and have an important role in cardiovascular cell signaling. In this review, we will therefore describe the state of knowledge concerning the regulatory role of GPCRs in both the generation and function of pluripotent stem cell derived-cardiomyocytes, -endothelial, and -vascular smooth muscle cells. We will consider how far the in vitro disease models recapitulate authentic GPCR signaling and provide a useful basis for discovery of disease mechanisms or design of therapeutic strategies.

Keywords: G-protein coupled receptor, Pluripotent stem cells, cardiovascular, disease modeling

\section{GENERAL DESCRIPTION OF GPCRs}

G-proteins are heterotrimeric proteins consisting of $\alpha, \beta$, and $\gamma$ subunits that can bind to both guanosine triphosphate (GTP) and guanosine diphosphate (GDP) nucleotides. G-protein-coupled receptors (GPCRs) are seven-transmembrane domain receptors (7TM receptors), which function through their interaction with G-proteins inside the cell. They can amplify extracellular signals to

Abbreviations: 7TM receptors, seven-transmembrane domain receptors; $\alpha$-ARs, $\alpha$-adrenergic receptor; AC, adenylyl cyclase; ACE, angiotensin converting enzyme; ANF, atrial natriuretic factor; APC, adenomatosis polyposis coli; $\mathrm{AT}_{1}$, angiotensin receptor1; $\beta$-AR, $\beta$-adrenergic receptor; $\mathrm{BBB}$, blood-brain barrier; $\mathrm{BMP} 4$, bone morphogenetic protein 4; BNP, B-type natriuretic peptide; cAMP, 3',5'-Cyclic adenosine monophosphate; CK1a, casein kinase 1a; CRISPR, clustered regularly interspaced short palindromic repeat; DCM, dilated cardiomyopathy; DMD, Duchenne muscular dystrophy; DVL, Disheveled; EC, endothelial cell; ECM, extracellular matrix; ERK1/2, extracellular signal-regulated kinases 1/2; $\mathrm{ET}_{\mathrm{A}}$, endothelinreceptor A; FGF, fibroblast growth factor; FZD, Frizzled receptor; GDP, guanosine diphosphate; Gi, guaninecoupled inhibitory protein; GSK3, glycogen synthase kinase 3; GPCR, G-protein coupled receptors; Gs, guanine-coupled stimulatory protein; GTP, guanosine triphosphate; HCM, hypertrophic cardiomyopathy; hESC, human embryonic stem cells; HF, heart failure; HGP, Hutchinson-Gilford progeria syndrome; hPSC, human pluripotent stem cells; JNK, c-Jun amino (N)terminal kinase; IP3, inositol-1,4,5-triphosphate; LEF lymphoid enhancer factor; LPA, lysophosphatidic acid; LQT, long QT syndrome; mESC, murine ESC; MI, myocardial Infarction; NFAT, nuclear factor of activated T-cells; PAF, platelet activating factor; PDGF, platelet derived growth factor; PE, phenylephrine; PI3-K, phosphoinositide 3-kinase; PKA, protein kinase A; PKC, protein kinase C; PLC, phospholipase C; PP2A, protein phosphatase 2A; PSC-EC, pluripotent stem cell-derived endothelial cells; PTX, pertussis toxin; S1P, sphingosine 1 phosphate; SDF1, stromal cell derived factor 1; SFRP, secreted frizzled related protein; SM, smooth muscle; T3, triiodothyronine; TCF T-cell factor; TGF- $\beta$, transforming growth factor $\beta$; VEGF, vascular endothelial growth factor; VSMC, vascular smooth muscle cell; ZFN, zinc finger nuclease. 
produce robust, varied, and cell-specific responses including chemotaxis, neurotransmission, cell growth, differentiation, and communication. GPCRs can bind a diverse range of ligands from large proteins to photons (Kristiansen, 2004) and also have a wide range of ligand-binding mechanisms (Gether et al., 2002). There are more than 800 GPCRs in the human genome, making it the largest receptor superfamily. GPCRs are divided into five distinct families using bioinformatic analysis: Glutamate, Rhodopsin, Adhesion, Frizzled, and Secretin (GRAFS classification system; Fredriksson et al., 2003; Gloriam et al., 2007). An up-to-date list of all human GPCRs as agreed by the International Union of Pharmacology subcommittee on Receptor Nomenclature and Drug Classification (NCIUPHAR) can be found at http://www.guidetopharmacology. org/.

GPCR signaling is activated via the receptor G-protein $\alpha$ subunit, which can be divided into four major classes comprising of $G_{s}, G_{i}, G_{q}$, and $G_{12 / 13}$, with each class consisting of multiple subtypes. To date $16 \alpha$ subunits have been identified, with a total of 23 different isoforms. In addition, $5 \beta$ subunits and $12 \gamma$ subunits have also been identified in the human genome. There are multiple combinations of various isoforms that exist for each of the three G-protein subunits and the signaling pathways activated by them (Figure 1; Li et al., 2002; Tuteja, 2009).

While all GPCRs share common features like 7TM structure, interaction with the intracellular heterotrimeric $G$ proteins and internalization, it is important to note that Frizzled (FZD) receptors which consist of 10 members and are classed separately in this superfamily do not all follow the same signaling mechanism as the other members and will be further discussed later (Foord et al., 2005; Gloriam et al., 2007).

Approximately $50-60 \%$ of all existing medicines are believed to target GPCRs (Fredriksson et al., 2003). By identifying the physiological role of GPCRs and their respective downstream signaling pathways, our understanding of many cardiovascular conditions has increased and new treatments have been developed. Indeed, two of the most prognostically important medications in treating heart failure target GPCRs and their pathways: (1) beta-adrenergic ( $\beta$-AR) pathway blockers and (2) angiotensin converting enzyme (ACE) inhibitors/Angiotensin II receptor type 1 blockers (Kober et al., 1995; Salazar et al., 2007; Hunt et al., 2009; McMurray et al., 2012). Among an estimated 200 cardiac GPCRs (Salazar et al., 2007), drugs targeting adrenergic and angiotensin pathways alone account for the majority of prescriptions in cardiovascular diseases (Tang and Insel, 2004). In this review we aim to give an overview of the role of GPCRs in human pluripotent stem cells and their cardiovascular derivatives.

\section{GPCRs IN HUMAN PLURIPOTENT STEM CELLS (hPSC)}

GPCRs exert a multitude of effects in pluripotent stem cells. A wide range of GPCRs are expressed in human embryonic stem cells (hESCs; Nakamura et al., 2009; Layden et al., 2010). Evidence exists for their roles in stem cell maintenance (Pébay et al., 2005; Inniss and Moore, 2006; Wong et al., 2007), pluripotency/selfrenewal (Faherty et al., 2007; Kobayashi et al., 2010; Layden et al., 2010; Callihan et al., 2011), migration (McGrath et al., 1999; Miller et al., 2008) and survival (Jiang et al., 2007; Wong et al., 2007; summarized in Table 1). Less research however has been performed with human induced pluripotent stem cells (hiPSC).

\section{Maintenance and Survival}

GPCRs have an important role in stem cell maintenance. Lysophospholipid signaling, mediated by sphingosine-1phosphate (S1P) and lysophosphatidic acid (LPA), control a wide range of cellular processes including stem cell maintenance via their respective GPCRs; $\mathrm{S}_{1} \mathrm{P}_{1-5}$ and $\mathrm{LPA}_{1-5}$. Signaling is mediated through phospholipase C (PLC), extracellular signal-regulated kinases $1 / 2$ (ERK1/2), adenylate cyclase (AC), $\mathrm{Ca}^{2+}$ mobilization and activation of small GTPases. hESCs express both $\mathrm{S}_{1} \mathrm{P}_{1-3}$ and $\mathrm{LPA}_{1-5}$ (Pébay et al., 2005; Dottori et al., 2008). S1P in combination with platelet derived growth factor (PDGF) is responsible for the maintenance of hESC in an undifferentiated state via $\mathrm{G}_{\mathrm{i}^{-}}$and ERK-dependent mechanisms leading to the activation of pro-survival pathways, apoptosis inhibition and increased proliferation (Pébay et al., 2005; Inniss and Moore, 2006; Wong et al., 2007). From studies performed in murine ESC (mESC) expression of both $\mathrm{CB} 1$ and $\mathrm{CB} 2$

TABLE 1 | GPCRs with roles in hESC/hiPSC and differentiation to cardiovascular derivatives.

\begin{tabular}{|c|c|c|c|c|}
\hline & GPCR & Species & Cell type & References \\
\hline \multirow[t]{4}{*}{$\begin{array}{l}\text { Maintenance } \\
\text { and survival }\end{array}$} & S1P & Human & ESC & $\begin{array}{l}\text { Pébay et al., 2005; } \\
\text { Inniss and Moore, } \\
\text { 2006; Wong et al., } \\
2007\end{array}$ \\
\hline & LPA & Human & ESC & Dottori et al., 2008 \\
\hline & $\mathrm{CB} 1$ and $\mathrm{CB} 2$ & Murine & ESC & Jiang et al., 2007 \\
\hline & CXCR4 & Murine & ESC & Guo et al., 2005 \\
\hline $\begin{array}{l}\text { Self renewal/ } \\
\text { pluripotency }\end{array}$ & FZD & Human & ESC & $\begin{array}{l}\text { Sato et al., 2004; } \\
\text { Cai et al., 2007; } \\
\text { Melchior et al., } \\
2008\end{array}$ \\
\hline
\end{tabular}

\begin{tabular}{|c|c|c|c|c|}
\hline Migration & CXCR4 & Murine & ESC & Guo et al., 2005 \\
\hline \multirow[t]{2}{*}{$\begin{array}{l}\text { Reprogramming } \\
\text { to iPSC }\end{array}$} & FZD & Murine & iPSC & $\begin{array}{l}\text { Marson et al., } \\
\text { 2008; Li et al., } \\
2011\end{array}$ \\
\hline & & Human & iPSC & Li et al., 2009 \\
\hline
\end{tabular}

\begin{tabular}{|c|c|c|c|c|}
\hline \multirow[t]{3}{*}{$\begin{array}{l}\text { Cardiac } \\
\text { differentiation }\end{array}$} & FZD & Human & ESC/iPSC & $\begin{array}{l}\text { Lian et al., 2012; } \\
\text { Minami et al., } 2012\end{array}$ \\
\hline & APJ & Human & ESC & Wang et al., 2012 \\
\hline & AT & Murine & ESC & Wu et al., 2013 \\
\hline $\begin{array}{l}\text { Endothelial } \\
\text { differentiation }\end{array}$ & FZD & Human & iPSC & $\begin{array}{l}\text { Lippmann et al., } \\
\text { 2012; Lian et al., } \\
2014\end{array}$ \\
\hline
\end{tabular}




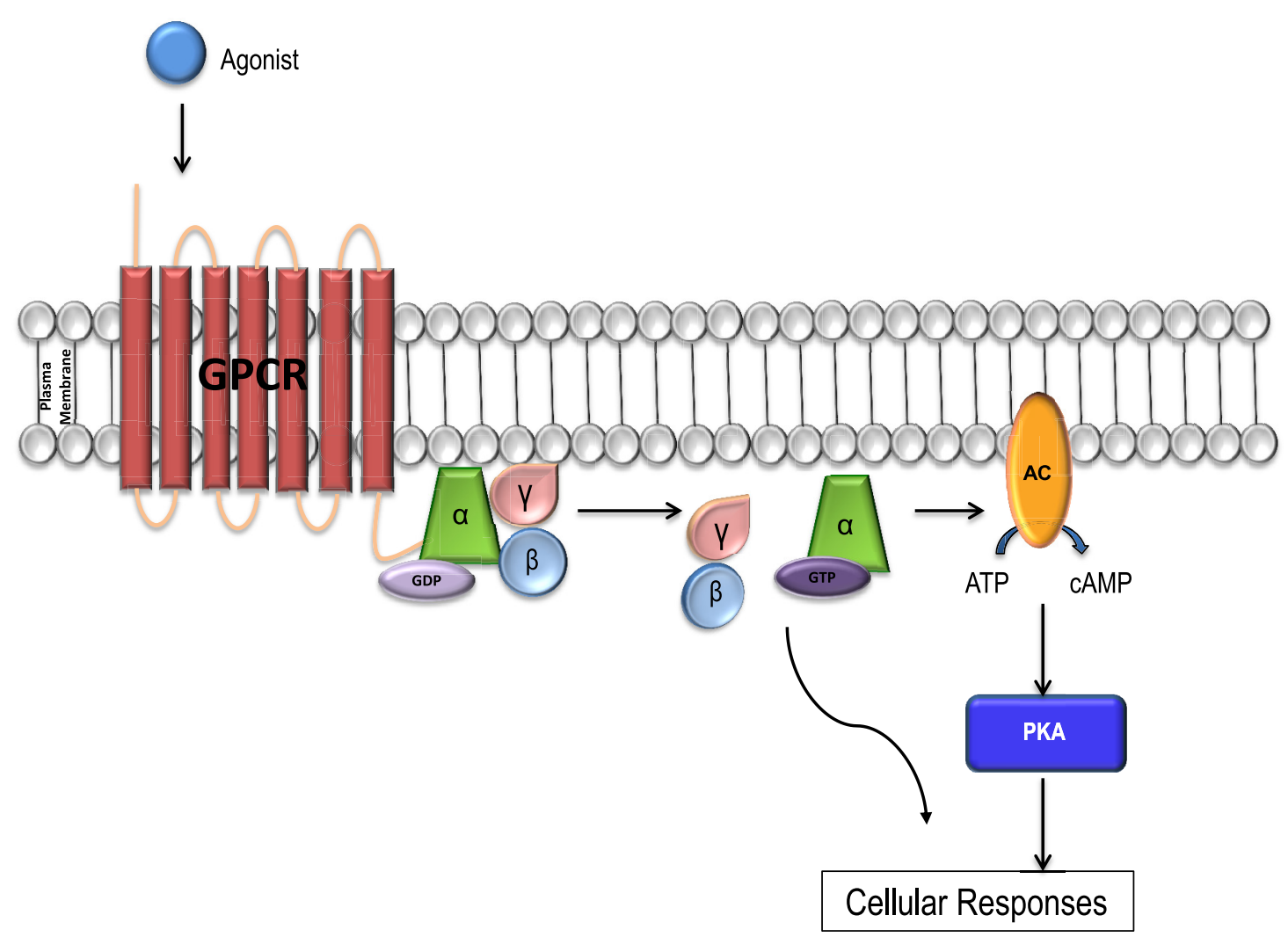

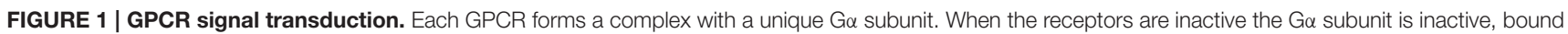
to GDP and in a heterotrimeric conformation with $\beta \gamma$-subunits. The $\alpha$ and $\gamma$ subunits are attached to the plasma membrane by lipid anchors. Once bound to a ligand, the receptor is activated and undergoes a conformational change, and the $\mathrm{G} \alpha$ subunit releases GDP, binds to GTP and is activated. The $\mathrm{G}_{\alpha}$ subunit then releases the $\beta \gamma$ complex leading to the activation of a variety of downstream effector molecules by the $\mathrm{G} \alpha$ subunit and $\beta \gamma$ complex separately. The activated G $\alpha$ subunit can bind to and activate a number of enzymes including adenylyl cyclase (AC) which catalyzes ATP into cAMP. Increases in the concentration of cAMP lead to the activation of the PKA enzyme which in turn activates the downstream signaling pathways resulting in a variety of cellular responses including glucose regulation and inotropy. The cycle is completed when $G_{\alpha}$-GTPase hydrolyzes GTP to GDP and becomes inactive. The G protein complex then re-couples the Ga with the $G_{\beta \gamma}$ subunit.

cannabinoid receptors have been detected and demonstrated to have a role in ESC survival (Jiang et al., 2007). Furthermore, the expression of the endocannabinoid receptor, 2-AG, may also contribute to ESC survival. The stromal cell derived factor 1 (SDF1 or CXCL12)/CXCR4 pathway which is widely known for its role in cell migration has also been found to enhance survival of mESC (Guo et al., 2005). To date, the role of these pathways has not been thoroughly investigated in hESCs/hiPSCs.

\section{Self-renewal/Pluripotency}

Expression and activation of $\mathrm{G}_{\mathrm{s}^{-}}$and $\mathrm{G}_{\mathrm{i}}$-coupled GPCRs have been implicated in stem cell pluripotency in hESC and hiPSC (Nakamura et al., 2009). Colony morphology correlates closely with the maintenance of pluripotency. $\mathrm{G}_{\mathrm{i}}$ inhibition with pertussis toxin (PTX) results in hiPSC/hESC colonies with a multi-layered appearance in contrast to a normal flat morphology, thereby preventing colony outgrowth (Nakamura et al., 2009). Proliferation, pluripotency and cell survival however, were unaffected by $G_{i}$ inhibition. $G_{s}$ activation on the other hand has been found to have no effect on colony morphology. While there is little evidence available in hPSCs, the activation of the $\mathrm{G}_{\alpha \mathrm{s}}$-cAMP signaling pathway in mESCs contributes to the maintenance of transcription factor expression which is important for pluripotency (Layden et al., 2010). In addition, evidence exists for the involvement of the cAMP/PKA pathway in mESC self-renewal pathways (Faherty et al., 2007).

One of the key signaling pathways implicated in ESC selfrenewal and pluripotency is the Wnt pathway. This signaling pathway can manifest in one of the three ways: (i) the canonical $\mathrm{Wnt} / \beta$-catenin, (ii) Wnt/planar cell polarity (PCP) and (iii) Wnt/calcium pathways (Huang and Klein, 2004; Figure 2). Wnt ligands are lipid modified glycoproteins which bind to a Frizzled (FZD) receptors and a co-receptor; LRP 5/6. The co-receptor varies depending upon the signaling pathway.

In the past, while the $\mathrm{Wnt} / \mathrm{Ca}^{2+}$ branch was recognized as the $G$ protein-dependent pathway, the $\mathrm{Wnt} / ß$-catenin and Wnt/PCP signaling pathways were regarded as heterotrimeric $\mathrm{G}$ protein-independent. However, many important studies have more recently shown that heterotrimeric $G$ proteins play a more global role in the general Wnt signaling pathway (Katanaev 

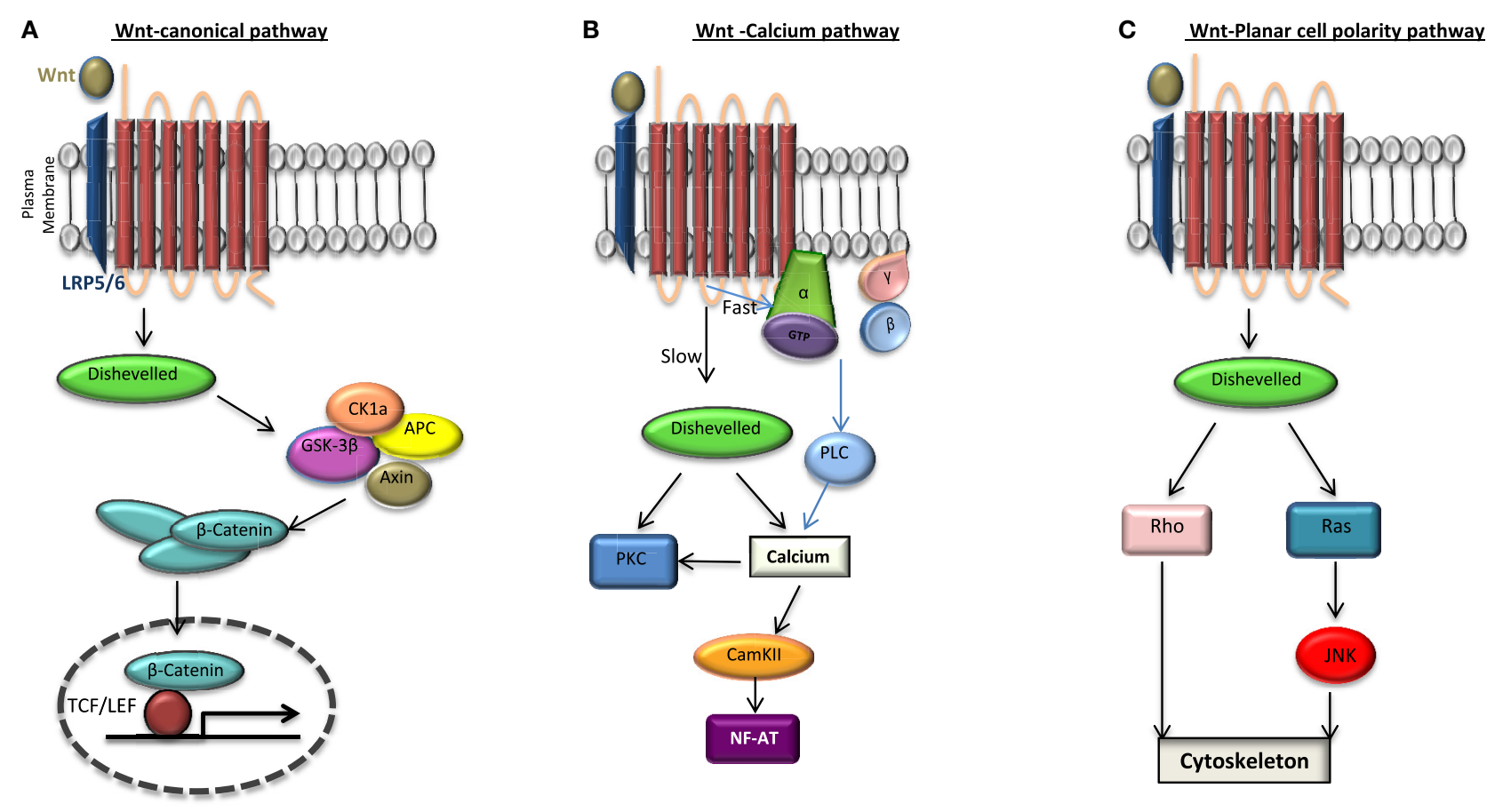

FIGURE 2 | Wnt signaling pathways. When Frizzled receptor (FZD) is bound to its agonist Wnt it can activate one of the three pathways: (A) the canonical pathway in which the activation of disheveled (DVL) leads to the disassembly of the destruction complex; axin, adenomatosis polysis coli (APC), glycogen synthase kinase $3 \beta$ (GSK3 $\beta$ ) from $\beta$-catenin. This in turn increases the cytosolic level of $\beta$-catenin which is then translocated to the nucleus and binds to transcription factor T-cell factor/lymphoid enhancer factor (TCF/LEF) activating the transcription of target genes. $\beta$-catenin is phosphorylated by GSK3 $\beta$ and degraded when there is no Wnt activation of FZD. Non canonical pathways include (B) Wnt-Calcium pathway in which DVL activates protein kinase C (PKC) leading to the release of intracellular calcium thereby activating a calcium/calmodulin-dependent protein kinase II (CaMKII) and (C) Wnt-planar cell polarity pathway in which the activation of DVL signals to Rho GTPases (Rho or Rac or both). While Ras activation is signaled through the c-Jun amino (N)-terminal kinase (JNK), the activation of Rho-GTPases induces changes in the cytoskeleton. To date it has been found that Wnt signaling can not only lead to a direct activation of DVL independent of the heterotrimeric G proteins as seen in (A) but may also lead to a G protein-DVL dependent activation whereby DVL can bind to or become activated subsequently by the G proteins in the cell.

et al., 2005; Egger-Adam and Katanaev, 2008). Since the two intracellular scaffolding proteins for FZD are heterotrimeric G proteins and Disheveled (DVL), what is still not clear in this field is the nature of this interaction and signaling following an agonist binding. Depending on the intermediary involvement of the DVL this interaction can be either direct or indirect. In a direct interaction FZD can act as either (a) a guanine nucleotide exchange factor (GEF), catalyzing the exchange of GDP for GTP on the $\mathrm{G}_{\alpha \mathrm{s}}$ subunit, releasing $\mathrm{GTP}-\mathrm{G}_{\alpha}$ and $\mathrm{G}_{\beta \gamma}$ or (b) a guanine dissociation inhibitor (GDI) sequestering GDP- $\mathrm{G}_{\alpha}$ releasing $\mathrm{G}_{\beta \gamma}$. However, in the indirect model of interaction FZD may be acting through a higher order complex consisting of FZD, DVL, and the heterotrimeric $G$ protein complex, whereby the FZD $-G_{\alpha} G_{\beta} G_{\gamma}$ binding and signaling is via DVL (Klipp and Liebermeister, 2006; Schulte and Bryja, 2007; Nichols et al., 2013).

Expression of the pluripotency genes Sox-2, Nanog, OCT3/4 and brachyury are targets of the Wnt/ $\beta$-catenin pathway (Sokol, 2011). hESCs have been shown to express Wnt1, members of the frizzled receptor family $\mathrm{FZD}_{1,3-6}$ and secreted frizzled related protein (SFRP) family (SFRP1, SFRP2, FRZB, SFRP4; Walsh and Andrews, 2003). The SFRP family act as antagonists to the Wnt pathway. There is contrasting evidence to support the role of Wnt signaling in hESC. Wnt3a and Wnt1 have been shown to stimulate hESC proliferation and maintain pluripotency via the canonical Wnt signaling pathway (Sato et al., 2004; Cai et al., 2007). In contrast, Wnt/ $\beta$-catenin activation did not maintain the undifferentiated and pluripotent state of hESC (Dravid et al., 2005). The Wnt receptor $\mathrm{FZD}_{7}$ has also been identified as important for hESC maintenance and self-renewal. Loss of OCT4 expression and alterations to colony morphology were observed after knockdown of $\mathrm{FZD}_{7}$ (Melchior et al., 2008).

\section{Cell Migration}

In addition to contributing to stem cell maintenance, the SDF1/CXCR4 pathway is important in endogenous stem cell trafficking during embryogenesis (McGrath et al., 1999; Miller et al., 2008). Activation of CXCR4 by SDF1 stimulates a number of pathways involved in motility, chemotaxis, adhesion and secretion, via activation of a number of signaling cascades including: adhesion, PI-3K-AKT, MEK-MAPK p42/44, and JAK/STAT (reviewed in Kucia et al., 2004). Both SDF1 and CXCR4 expression have been detected in mESCs and have been shown to be chemotactic for these cells (Guo et al., 2005). Priming of this pathway with sphingosine 1 phosphate (S1P) prior to the transplantation of cells enhanced cardiac and vascular remodeling in a rat model of pulmonary arterial hypertension 
(Kang et al., 2015). At the time of writing this review no evidence existed for the expression of SDF/CXCR4 in hESC or hiPSC.

\section{Reprogramming Somatic Cells to iPSC}

The modulation of the Wnt signaling pathway appears to play a role in reprogramming. Inhibition of the downstream signaling molecule, GSK3, has the potential to replace Klf4 in the Yamanaka reprogramming cocktail in murine cells (Lyssiotis et al., 2009). The use of a combination of different small molecules, including the GSK3 $\beta$ inhibitor CHIR99021, has been reported to induced murine iPSC reprogramming in the presence of a single transcription factor (OCT4; Li et al., 2011). Additionally, CHIR99021 in combination with an inhibitor of lysine-specific demethylase, has been used in the presence of OCT4 and Klf4 to successfully reprogram human keratinocytes (Li et al., 2009). Application of Wnt3a has been reported to enhance reprogramming in conjunction with Klf4/OCT4/SOX2 in the absence of c-myc (Marson et al., 2008). A cocktail of small molecules, including the cAMP activator forskolin, has also been shown to have the potential to replace OCT4 during murine iPSC-reprogramming (Hou et al., 2013). In addition to the expression of the Yamanaka transcription factors, morphological changes are necessary for cellular reprogramming.

\section{GPCRs IN CARDIOVASCULAR DIFFERENTIATION}

GPCRs have a fundamental role in early and late mesoderm formation during development and cardiovascular cell differentiation. To date, there are three platforms for cardiovascular cell differentiation: monolayer, embryoid body (EB) and microcarrier cultures. The efficiency of these methods depends on several factors including: (a) the biomolecules used (growth factors or small molecule inhibitors), (b) the condition of the hPSC culture expansion, and (c) the activation or deactivation time of molecular signals in guiding the differentiation toward cardiovascular lineages (Chen et al., 2014). Differentiation is achieved through the coordination of diverse molecular pathways. Elucidation of the complex molecular signals that are evoked during hPSC differentiation have enabled specific targeting of their activities to enhance cell differentiation and promote tissue regeneration.

Earlier protocols for the production of cardiomyocytes (CMs; Xu et al., 2002; Zhang et al., 2009), endothelial cells (ECs; Goldman et al., 2009; Földes et al., 2010) and vascular smooth muscle cells (VSMCs; Ge et al., 2012; Dash et al., 2015) relied on EB formation, whereby hPSC undergo spontaneous differentiation following the formation of 3D, non-adherent structures. Although this method generated cells of the required lineages, it was relatively inefficient. Differentiation has been much improved in recent years with use of factors found to be involved in mesoderm formation in vivo. GPCR Wnt signaling molecules and non-GPCR fibroblast growth factor (FGF), bone morphogenetic protein 4 (BMP4) and Activin A are all widely used for cardiomyocyte differentiation (Laflamme et al., 2007; Yang et al., 2008). In all protocols, the concentrations and duration of each treatment depends on the platform as well as the hPSC line in use.

For endothelial cell differentiation growth factors frequently utilize FGF2, which has been shown to promote the formation of endothelial progenitors (Evseenko et al., 2010), and BMP-4, which acts to accelerate commitment to the endothelial lineage (Goldman et al., 2009). Amongst the key pro-angiogenic growth factors, vascular endothelial growth factor (VEGF) is arguably the most important and has been demonstrated by multiple studies to dramatically increase the yield of ECs during differentiation (Tatsumi et al., 2011; Adams et al., 2013). GPCR agonists such as thrombin and angiotensin II can directly modulate vascular remodeling and they can also act indirectly through the induction of VEGF (Richard et al., 2001).

Various differentiation protocols have been validated and replicated to differentiate pluripotent stem cells into vascular smooth muscle (VSMC) like cells with mature characteristics displaying cellular markers (smooth muscle $\alpha$-actin, calponin) and an adult morphology (fibrous). In addition, they display similar contractile responses to agonists such as carbachol (Ge et al., 2012; Karamariti et al., 2013; Wanjare et al., 2013; Sinha et al., 2014; Dash et al., 2015). For generating smooth muscle cells, various limitations using the EB method of differentiation led researchers to develop improved protocols of VSMC differentiation from hiPSC using monolayers of extracellular matrix (ECM) proteins in the presence of PDGF subunit $\mathrm{B}$ homodimer (PDGF-BB) and transforming growth factor beta (TGF- $\beta$; Karamariti et al., 2013; Wanjare et al., 2013) and heparin (Bajpai et al., 2012).

\section{Frizzled Receptor}

Wnt signaling is necessary for different steps of the cardiac development in embryonic stem cells, including myocardial specification, cardiac morphogenesis, and cardiac valve formation (Korkaya et al., 2009). It is believed the non-canonical Wnt pathway plays a key role in cardiac morphogenesis and affects the specification and expansion of cardiac progenitor cells (Korkaya et al., 2009). Hence, most of the latest protocols in the differentiation of hPSCs to CMs involve the use of various Wnt inhibitors and downstream molecules like GSK3 $\beta$.

Of the three stages of cardiomyocyte differentiation: mesodermal induction, cardiac progenitor generation and cardiomyocyte generation and maintenance, the initial step of mesoderm induction is induced by the activation of the TGF- $\beta$ pathway (Watabe and Miyazono, 2009; Xu, 2012). This can be achieved by the use of growth factors, BMP4 and Activin A. An indirect activation of the TGF- $\beta$ signaling pathway has been performed in vitro by using small molecules, such as GSK3 $\beta$ inhibitors (CHIR99021 or BIO) which have an increasing effect on the endogenous levels of BMP2/4 (Lian et al., 2012; Minami et al., 2012). For the second stage of cardiac progenitor induction the TGF- $\beta$ pathway has to be inactivated. This can be achieved by: (a) the removal of the activators and addition of growth factors including FGF2 and/or VEGF, which activate the ERK signaling pathway, or (b) the addition of small molecule Wnt inhibitors (KY02111, XAV939, DKK1, IWP-2, and IWR-1; Chen et al., 2006). This results in the formation of the cardiac 
progenitor lineage from mesodermal cells and inhibits the development of smooth muscle and endothelial cell lineages (Woll et al., 2008; Yang et al., 2008). The final stage of CM generation and maintenance, which takes place from day 8 is also found to be dependent on the inhibition of the $\mathrm{Wnt} / \beta$-catenin signaling pathway (Gessert and Kühl, 2010). It can therefore be concluded that Wnt signaling plays a biphasic role in human cardiogenesis, being both activated during the early phase and inhibited during the late phase of cardiac differentiation (Lian et al., 2012).

During fetal growth the compact myocardium proliferates more rapidly when compared to the trabecular myocardium in luminal regions of the heart (Jeter and Cameron, 1971; Luxán et al., 2013). The proliferation of fetal cardiomyocytes in this region is necessary for the correct morphogenesis of ventricular myocardium, trabeculae, and chamber cavities. It has recently been shown that this regional expansion of ventricular myocytes is regulated by the $\mathrm{Wnt} / \beta$-catenin pathway. The increase in the ventricular proliferation is maintained until birth. This fetal Wnt signaling pathway is re-expressed upon myocardial infarction and induced ischemic heart injury in mice (Buikema et al., $2013 a, b)$. Hence, it has been suggested that in adult myocardium $\mathrm{Wnt} / \beta$-catenin may play a role in endogenous cardiac repair; however, the exact role of this pathway in the adult cardiac homeostasis is not yet known (Oka et al., 2007; Oerlemans et al., 2010).

In addition, the production of pluripotent stem cell-derived endothelial cells (PSC-EC) has also been shown to be dependent on small molecule activation of canonical Wnt signaling. This was demonstrated to be an effective mechanism using a $2 \mathrm{D}$ culture system, even in the absence of exogenous VEGF (Lian et al., 2014). The canonical Wnt ligands, Wnt7a and Wnt7b, have been implicated in blood-brain barrier (BBB) development in vivo (Daneman et al., 2009). In order to generate human BBB-ECs, the Wnt pathway was targeted in differentiating hPSCs (Lippmann et al., 2012). A Wnt target gene called Stimulated by retinoic acid 6 (STRA6) which acts as a vitamin A transporter is found in the BBB (Szeto et al., 2001). It is highly expressed in adult brain ECs in comparison to lung or liver cells, and is up-regulated during the course of BBB cell differentiation (Lippmann et al., 2012).

\section{Angiotensin Receptor}

Angiotensin receptors are members of the GPCR family and are composed of two main types; angiotensin receptors I and II ( $\mathrm{AT}_{1}$ and $\mathrm{AT}_{2}$ ) which exhibit similar affinities for angiotensin II (Ang II; de Gasparo et al., 2000). The activated $A_{1}$ binds to $G_{q / 11}$ and $\mathrm{G}_{\mathrm{i} / \mathrm{o}}$ to activate phospholipase $\mathrm{C}$ and increase the cytosolic $\mathrm{Ca}^{2+}$ concentration, whilst $\mathrm{AT}_{2}$ exerts its effect via coupling to the $\mathrm{G}_{\mathrm{i} 2 / 3}$ components of the heterotrimeric G-proteins (Higuchi et al., 2007). Activated $\mathrm{AT}_{1}$ and $\mathrm{AT}_{2}$ have mutually counteracting hemodynamic effects in the cardiovascular system. $\mathrm{AT}_{1}$ is believed to be responsible for the contractile response while $\mathrm{AT}_{2}$ is involved in the relaxation response to Ang II (Batenburg et al., 2004). Ang II promotes the differentiation of mESC-CM through $\mathrm{AT}_{1}$ (Wu et al., 2013). Currently no role in human cardiovascular differentiation has been described. $\mathrm{AT}_{1}$ and $\mathrm{AT}_{2}$ are expressed on human hemangioblasts. The differentiation into endothelial progenitors can be influenced by modulating the signaling through these receptors. ACE activity is required for hemangioblast expansion. $\mathrm{AT}_{1}$ - or $\mathrm{AT}_{2}$ specific inhibitors dramatically augment endothelial differentiation (Zambidis et al., 2008).

\section{Apelin Receptor}

This receptor, also known as Angiotensin receptor like 1 (AGTRL1 or APJ) is a member of the GPCR family that binds apelin (APLN; Tatemoto et al., 1998; Lee et al., 2000) and ELABELA/Toddler (Chng et al., 2013; Pauli et al., 2014). APJ is coupled to $G_{i}$ and/or $G_{q}$ and is expressed in the mesodermal cells of the secondary heart field in mouse embryo. It couples extracellular signaling with chromatin modifications in pluripotent stem cell cardiomyogenesis (D'Aniello et al., 2013). During hESC differentiation, APJ marks mesodermal precursors (Vodyanik et al., 2010). While on adult cardiomyocytes, the expression of this receptor is a potent regulator of contractility (Szokodi et al., 2002; Berry et al., 2004; Ashley et al., 2005); on early embryonic cells it is believed to regulate the migration of progenitor cells fated for cardiomyocyte differentiation (Scott et al., 2007; Zeng et al., 2007). Hence, Apelin has been used in the differentiation of both mouse and human ESCs to cardiomyocytes in combination with mesodermal differentiation factors including BMP4, bFGF, and Activin A. Using an EB differentiation method and by administering these factors in a specific temporal sequence, it has been shown that apelin can indeed promote cardiac differentiation and lead to earlier beating EBs when compared to controls (Wang et al., 2015). We and others have shown that APJ and one of its ligands apelin have an important regulatory role in angiogenesis (Scott et al., 2007). A second ligand elabela (or Toddler) has been recently discovered which is required for the normal development of vasculature through activation of APJ. Elabela/APJ signaling pathway was shown to be functional in the human system as well (Chng et al., 2013; Wang et al., 2015). To date, no published data is available for the new ligand in hPSCs.

\section{Lysophospholipid Signaling}

Lysophospholipid signaling is important for vascular development and maturation, but in vitro stem cell models are currently lacking. Knockout mice of $\mathrm{S}_{1} \mathrm{P}_{1} \quad\left(\mathrm{G}_{\mathrm{i}}\right.$-coupled receptor for sphingosine-1 phosphate) has been showing high lethality at E12.5 (Soriano, 1999).This has been attributed to the necessary function of ECs (Kataoka et al., 2003) and the receptor has also been found to be essential for vascular maturation (Liu et al., 2000). Furthermore, in vivo studies have shown that S1P protein synergizes with FGF-2 and VEGF in angiogenesis and vascular maturation through $\mathrm{S}_{1} \mathrm{P}_{1}$ (Garcia et al., 2001). While $S 1 P_{1}$ couples directly to the $G_{i}$ pathway, the other receptor isoforms known also as endothelial differentiation gene 3, 5 (Edg-3 and -5) stimulate $\mathrm{G}_{\mathrm{i}}, \mathrm{G}_{\mathrm{q}}$, and $\mathrm{G}_{13}$ pathways (Ancellin and Hla, 1999; Windh et al., 1999).

\section{Protease-activated Receptor-1}

Protease-activated receptor-1 (PAR-1) is one of the four members of the PAR subfamily of GPCRs, which are highly expressed 
in platelets as well as ECs, myocytes, and neurons (Macfarlane et al., 2001). PAR-1 is activated by serine proteases including thrombin, whereby the $\mathrm{N}$-terminus of the receptor is cleaved and this in turn acts a tethered ligand activating the receptor. As PARs are involved in maintaining hemostasis and thrombus formation in atherosclerotic vessels, these are being tested as drug targets (Sambrano et al., 2001). As a member of the receptor family, PAR-1 was shown to play a role in embryonic development (Griffin et al., 2001), partially via modulation of downstream signaling proteins such as the heteromeric G-protein subunit $\mathrm{G}_{\alpha 13}$ (Ruppel et al., 2005). The role in hPSC differentiation remains to be defined.

\section{Adrenergic Receptors}

Adrenergic receptors can be broadly divided into alpha ( $\alpha$-AR) and beta ( $\beta$-AR) receptors. The $\beta$-ARs have been shown to have a role in cardiomyocyte differentiation (Yan et al., 2011). $\beta_{1^{-}}$ ARs couple to stimulatory $G$ proteins $\left(G_{s}\right)$. Once stimulated, $G_{s}{ }^{-}$ proteins interact with the enzyme adenylyl cyclase $(\mathrm{AC})$, which in turn increases the production of cAMP. $\beta_{2}$-ARs and $\beta_{3}$-ARs can also couple to the inhibitory $G\left(G_{i}\right)$ protein (Gauthier et al., 1996; Gong et al., 2000). $\beta_{2}-A R G_{i}$ pathways decrease AC activation and cAMP production as well as the downstream phosphorylation of cardiac proteins including troponin I, myosin-binding protein $\mathrm{C}$ and L-type calcium channels. The net result opposes the action of the $\mathrm{G}_{\mathrm{s}}$ resulting in reduced contraction of the cardiac myocytes (Xiao et al., 1995; Woo and Xiao, 2012). Further studies in mESCs have shown that $\beta$-ARs play a role in ESC$\mathrm{CM}$ differentiation via ERK and $\mathrm{p} 38$ activation using $\beta$-AR agonists. $\beta_{1}$-ARs and $\beta_{2}$-ARs have been found at different stages of cardiac differentiation both at mRNA and protein levels. The expression of $\beta_{1}$-AR is lower than $\beta_{2}$-AR until day 7. After day 7 it increases gradually, reaching a peak at day 14 , and remains at a high level until day 21 . In contrast, $\beta_{2}-\mathrm{AR}$ is expressed at a high level even before differentiation, with no obvious change after inducing cardiac differentiation. It is therefore believed that $\beta_{2}$-AR might be the predominant subtype during the early stage of differentiation, while $\beta_{1}$-AR might be the predominant subtype for the late stage of cardiac differentiation (Yan et al., 2011).

\section{GPCRs IN PLURIPOTENT STEM CELL CARDIOVASCULAR DERIVATIVES}

In recent years, the ability to derive human cardiovascular cells from pluripotent stem cells, which have unlimited renewal capacity, has generated considerable interest. hPSC-derived cardiovascular derivatives have the potential to reduce the use of animal models and provide more physiologically relevant models of disease. They can be produced in quantities that are suitable for use in medium to high throughput screens, and platforms are being developed to measure their various functional outputs, including calcium transients, contraction, tubule formation, and cytotoxicity/signaling (Mioulane et al., 2012; Mercola et al., 2013; Stoehr et al., 2014; Simons et al., 2015). The relative ease of production and commercial availability further enhances their appeal for pharmaceutical screening and organ repair.

\section{Human Pluripotent Stem Cell-derived Cardiomyocytes \\ Alpha-adrenergic Receptors}

$\alpha$-ARs $\left(\alpha_{1 \mathrm{a}}, \alpha_{1 \mathrm{~b}}, \alpha_{1 \mathrm{~d}}\right)$ regulate the cardiovascular system by activating the $G_{\alpha q}$ pathway. Once activated, $G_{\alpha q}$ activates phospholipase C (PLC), which causes an increased myo-inositol-1,4,5-trisphosphate level and subsequent increase in calcium release from the endoplasmic reticulum (Exton, 1985; Salazar et al., 2007). These receptors are primarily thought to regulate blood pressure, inotropy and hypertrophy by cross talk between the $\alpha$-AR subtypes and also with $\beta$-ARs (Salazar et al., 2007). For example, overexpression of the $\alpha_{1 \mathrm{a}}$-AR increases cardiac contraction but not hypertrophy (Lin et al., 2001) and overexpression of $\alpha_{1 b}$-AR results in a decreased response to $\beta$-AR stimulation by isoprenaline left ventricular (LV) contractility, potentially as a result of additional $\mathrm{G}_{\mathrm{i}}$ coupling (Akhter et al., 1997). Additionally, a deficiency in the $\alpha_{1 b}$-AR receptor results in a blunted blood pressure response to the $\alpha_{1}$-AR receptor agonist phenylephrine (PE; Cavalli et al., 1997). Alpha-2-adrenergic receptors $\left(\alpha_{2}-\mathrm{AR}\right)$ are $\mathrm{G}_{\mathrm{i}}$-coupled receptors and oppose the action of $\mathrm{G}_{\mathrm{s}}$ signaling by inhibiting $\mathrm{AC}$ and therefore cAMP production and the various downstream sequelae (Salazar et al., 2007). $\alpha_{2}$-ARs are presynaptic and suppress presynaptic noradrenaline release and their role is to oppose the sympathetic stimulation of $\beta_{1}-\mathrm{AR}, \beta_{2}-\mathrm{AR}$, and $\alpha_{1}$-ARs during increased adrenergic stimulation. Their importance was shown with higher incidences of heart failure in patients with genetic polymorphisms resulting in the loss of function of $\alpha_{2}$-ARs (Small et al., 2002).

The expression of $\alpha$-ARs in hPSC-CMs, as reported by our own group, shows an early transient up-regulation during differentiation followed by a rapid stable down-regulation of ADRA1A in hiPSC-CM and hESC-CM. Conversely ADRA1B was found to be increased in an apparently compensatory manner. Other subtypes of $\alpha$-AR namely ADRA1D and ADRA2C have also been shown to be present in these cells, but the overall expression of these receptors and their G-proteins; $\mathrm{G}_{\mathrm{q}}$, $G_{\beta 1}$, and $G_{\gamma 2}$ is believed to be insufficient for the hypertrophic response to PE (Földes et al., 2014). However, when investigating the exact localization of $\alpha_{1}$-ARs in adult cardiomyocytes, recent studies found them expressed in the nuclei rather than just the sarcolemma itself: this may contribute to the differences observed in the response levels of various cell types to $\mathrm{PE}(\mathrm{Wu}$ and O'Connell, 2015).

\section{Beta-adrenergic Receptors}

There are three main types of $\beta$-ARs present in the human cardiovascular system; $\beta_{1}$-ARs are the most abundant accounting for $75-80 \%$ in healthy human hearts (Rockman et al., 2002); with $\beta_{2}$-ARs and $\beta_{3}$-ARs making up the remainder. $\beta_{1}$-ARs primarily modulate the inotropic and chronotropic responses of the human heart. Once activated, stimulatory $\mathrm{G}_{\mathrm{s}}$-proteins interact with $\mathrm{AC}$, which in turn increases the production of cAMP. The increased levels of cAMP result in increased binding to protein kinase A (PKA) and subsequent phosphorylation of many myocyte proteins (troponin I, voltage L-type calcium channels, cardiac ryanodine receptor) involved in cardiac contractility (Rockman 
et al., 2002; Xiang and Kobilka, 2003). The importance of $\beta_{1}$-ARs in cardiovascular regulation has been shown in $\beta_{1}$-AR knockout mice. Many did not survive past embryo stage and if they did, an increased heart rate in response to isoprenaline was found to be absent while the inotropic response to exercise/agonist stimulation was still present (Rohrer et al., 1996). On the other hand, transgenic mice with overexpression of $\beta_{1}$-ARs develop marked hypertrophy and increased contractility initially, but this is soon followed by the onset of heart failure (Engelhardt et al., 1999). $\beta_{2}$-ARs have some similarities with $\beta_{1}$-ARs in regulating contractility by utilizing $\mathrm{G}_{\mathrm{s}}$-proteins and the $\mathrm{AC}$ pathway with the eventual downstream release of calcium from L-type $\mathrm{Ca}^{2+}$ channels (Salazar et al., 2007). They differ in that $\beta_{2}$-ARs can additionally couple to $G_{i}$ (Daaka et al., 1997). Mice with overexpression of the $\beta_{2}-\mathrm{AR}$ at 60 -fold exhibited enhanced basal cardiac function without increased mortality when followed for 1 year. However, after 100-fold or more overexpression they developed a fibrotic cardiomyopathy and heart failure which increased in severity with overexpression level (Liggett et al., 2000). Knockout mice, however, display a relatively normal phenotype but develop a higher degree of hypertension in response to stress (exercise, adrenaline) when compared to control mice (Chruscinski et al., 1999). This may indicate the importance of the inhibitory G-coupled protein pathway in prolonged adrenergic stimulation (Salazar et al., 2007). $\beta_{3}$-ARs are expressed the least in the heart and their role in cardiovascular regulation is a little less certain with inotropic effects in response to agonists in mice overexpressing human $\beta_{3}$-ARs; however, a negative inotropic response in the human heart has been seen (Gauthier et al., 1996; Kohout et al., 2001). $\beta_{3}$-ARs are also up-regulated in human heart failure (Moniotte et al., 2001). Studies on hPSC-CMs have shown that $\beta$-AR responses are well developed in cardiomyocytes derived from hESCs and hiPSCs (Ali et al., 2004; Dambrot et al., 2014). Furthermore, the expression of both $\beta_{1}$-AR and $\beta_{2}$-AR has also been established, with $\beta_{1}$-AR being suggested as the predominant subtype for the late stage of cardiac differentiation (Wu et al., 2013, 2015).

\section{Angiotensin, Muscarinic, and Adenosine Receptors}

Other GPCRs also present on hPSC-CMs are ATs and muscarinic receptors as shown by expression studies and agonist responses in these cells. Muscarinic receptors reduce spontaneous beating rate in hPSC-CM from an early time after differentiation, although the muscarinic receptor subtype has not been delineated (BritoMartins et al., 2008). Adenosine can produce similar effects through the $A_{1}-\mathrm{R}$ in adult ventricular or atrial cardiomyocytes (Headrick et al., 2013) but to date no published data exists for hPSC-CMs. We have shown previously that angiotensin acting via $G_{q}$ can produce only a small increase in cell size in hESC$\mathrm{CM}$ despite a robust increase in the expression of both atrial natriuretic factor and B-type natriuretic peptide (ANF and BNP; Földes et al., 2008, 2014).

\section{Endothelin Receptors}

Endothelin receptors, specifically the endothelin-A $\left(\mathrm{ET}_{\mathrm{A}}\right)$ receptor, are subtypes of receptors involved in cardiac remodeling/hypertrophy. $\mathrm{ET}_{\mathrm{A}}$ is expressed in the cardiovascular system and has a plethora of roles including vasoconstriction, tachycardia, positive inotropy and hypertrophy (Concas et al., 1989; Salazar et al., 2007; Bupha-Intr et al., 2012). In addition, ET receptors are up-regulated in chronically failing human hearts (Asano et al., 2002; Salazar et al., 2007). In hPSC-CM, ET $\mathrm{A}_{\mathrm{A}}$ induces hypertrophic gene expression; such as BNP and ANF (Carlson et al., 2013; Földes et al., 2014). The exact downstream signaling mechanisms have not yet been published.

\section{Disease Modeling with hPSC-CM}

Predominant manifestations of pathology investigated in hPSC-CM are acute, including depressed contraction, electrophysiological alterations and arrhythmia, or longerterm, such as aberrant morphology, hypertrophy and increased susceptibility to cell death. While the acute characteristics have strong superficial similarities to adult cardiomyocytes, a clear difference in long term viability is seen in the prolonged survival in culture of hPSC-CM ( $>1$ year) compared to adult cells $(\sim 2$ days). This of course is one of the main attractions of hPSC-CM as a model system. Although proliferation rates in hPSC-CM are initially far higher than in adult cardiomyocytes, these drop rapidly around 1 month after differentiation, as the sarcomere structure develops (Földes et al., 2011). Morphology is initially less organized, but can develop with time or physical cues. The nature of the differences between adult and hPSC-CM phenotypes and the consequent limitations for modeling are discussed further below.

One pathological process where GPCR signaling plays a prominent role is cardiac hypertrophy. This is an adaptive response and is characterized by a thickening of cardiac myocytes. Physiological hypertrophy occurring in pregnancy and athletes is not detrimental and results in normal or enhanced heart function. In contrast pathophysiological hypertrophy, which can be caused by pressure overload in response to hypertension, myocardial infarction or other inherited conditions, leads to cardiac dysfunction and increased mortality. Approaches have been taken to model hypertrophy in vitro using hPSC-CM.

The predominant $\alpha$-ARs in the myocardium are $\alpha_{1}$-ARs (Brückner et al., 1985) and stimulation with catecholamines induces pathological cardiac hypertrophy (Rokosh et al., 1996; Zhong and Minneman, 1999). We have previously reported an increase in cell size in hESC-CM in response to the $\alpha$-AR agonist PE (Földes et al., 2011), attributed to activation of p38 MAPK signaling pathways. As described above, $\alpha_{1 \mathrm{~A}}-\mathrm{AR}$ gene expression was lost upon differentiation in hESC-CM (and hiPSC-CM), while $\alpha_{1 \mathrm{~B}}-\mathrm{AR}$ was up-regulated and mediated the hypertrophic response (Földes et al., 2014). In addition $\mathrm{ET}_{\mathrm{A}}$, Ang II and cyclic stretch also increased cell size in hESC-CM (Földes et al., 2011, 2014) with corresponding increases in ANF expression. $\beta_{2}$-AR stimulation did not induce cellular hypertrophy.

Hypertrophic responses in hiPSC-CM remain controversial. In contrast to hESC-CM, we found hiPSC-CM to be unresponsive to $\mathrm{PE}$, with cell size (assessed by high content automated microscopy) and ANF expression remaining unchanged (Földes et al., 2014). In addition, ET-1 and Ang II did 
not produce significant increases in cell size and correspondingly increased ANF and BNP expression was only seen in response to $\mathrm{ET}_{\mathrm{A}}$. Hypertrophic modeling in commercially available hiPSC-CM assays have been described which rely on detection of ANF expression in response to $\mathrm{ET}_{\mathrm{A}}$ (Aggarwal et al., 2014). In other studies, mild increases in hiPSC-CM size ( $\sim 10 \%$ or less) have been seen with PE, and up to 25\% with ET-1 (Carlson et al., 2013; Tanaka et al., 2014). In addition, enhanced myofibrillar disarray and nuclear factor of activated T-cells (NFAT) nuclear translocation were also reported (Zhi et al., 2012). There is conflicting data for the presence of cardiomyocyte hypertrophy in response to $\beta$-adrenergic stimulation. We found no increase in hiPSC-CM size (Földes et al., 2014), whereas Zhi and colleagues found the opposite (Zhi et al., 2012). It has been reported that serum containing media causes hypertrophy in hESC-CM and hiPSC-CM, which could explain the lack of cellular hypertrophy in response to hypertrophic stimuli in some studies (Dambrot et al., 2014). This was found not to be the explanation in our study (Földes et al., 2014); the difference between hESC$\mathrm{CM}$ and hiPSC-CM was caused rather by an imbalance in anti-hypertrophic signaling. It was also found that a combination of inhibitors could restore the PE response in hiPSC-CM.

A number of hiPSC-CM disease models have a hypertrophic phenotype, including LEOPARD syndrome and hypertrophic cardiomyopathy (HCM). Patient-derived HCM hiPSC-CM exhibit increased basal cell size compared to controls (Lan et al., 2013; Tanaka et al., 2014). $\beta$-AR stimulation exacerbates cellular hypertrophy in HCM cells (Lan et al., 2013). A hiPSCCM model of LEOPARD of syndrome exhibits a hypertrophic phenotype, displaying increased cell size and nuclear located NFAT (Carvajal-Vergara et al., 2010). It still remains to be determined whether HCM patient-derived cardiomyocytes or control cells treated with hypertrophic stimuli are the best model to use for the study of hypertrophy. Furthermore, a greater understanding of hypertrophic signaling in hPSC-CM is required to ensure conclusions drawn from these models are physiologically relevant.

In addition to hypertrophy, disease models have also provided further insight into pathological mechanisms involving GPCRs (Table 2). Patient-derived dilated cardiomyopathy (DCM) hiPSC-CMs display an increased susceptibility to stress. Desensitization of the $\beta$-AR response was observed in DCM hiPSC-CM both basally and in response to acute noradrenaline treatment (Sun et al., 2012). This goes against the current understanding of $\beta$-AR desensitization as an acquired characteristic of prolonged sympathetic stimulation in the heart failure patient. Either the troponin mutation has some mechanistic link to the control of $\beta$-AR function, or there is a co-inherited $\beta$-AR variant in this group of patients: either option is intriguing. In addition, long term $\beta$-AR stimulation resulted in sarcomeric disorganization and decreased inotropic and chronotropic responses. In patient-derived HCM hiPSC-CM, $\beta$ adrenergic stimulation also exacerbated the observed abnormal calcium handling and arrhythmia (Lan et al., 2013). In long QT syndrome (LQTS2 and LQTS1) hiPSC-CM models, arrhythmia was observed in response to $\beta$-adrenergic stimulation, which could be prevented using $\beta$-AR blockers (Tseng et al., 2006;
Matsa et al., 2011). This correlates with clinical observations, where $\beta$-AR blockers are routinely used to treat such conditions. The majority of these disease models originate from patient derived-hiPSC, but the trisomy 21 model described by Bosman and co-workers utilizes patient hESC-derived cardiomyocytes (Bosman et al., 2015). In this study trisomic cells showed an increased $\beta-A R$ response to isoprenaline in comparison to euploid control (Bosman et al., 2015).

\section{Vascular Derivatives}

ECs form a single-cell monolayer lining the blood vessels. Their essential functions include the ability to regulate vascular tone, vascular permeability, angiogenesis, platelet function and inflammatory responses (Michiels, 2003). ECs are involved in inflammation and interact closely with leukocytes. GPCRs expressed in these cells play a key role in sensing the presence of chemoattractants, transducing signals that lead to the production of cytokines and regulating vascular permeability (Table 3 ). ECs are therefore critical for vascular homeostasis, and cellular dysfunction is strongly associated with an increased risk of cardiovascular events (Lerman and Zeiher, 2005). Generating novel ECs is a powerful in vitro technique to study cellular responses under various culture conditions and to develop constructs for tissue engineering. PSC-ECs are suggested to have many of the properties of endogenous ECs and their phenotypes are being investigated to determine whether characteristics of vascular disease can be reproduced in vitro.

VSMCs have a plethora of roles in the cardiovascular system from producing extracellular matrix proteins which provide elasticity and the ability to withstand high circulating pressures to being involved in arterial repair and regulation of vascular tone. They are primarily contained in the media layer of blood vessels (Lacolley et al., 2012). The sympathetic nervous system regulates vascular tone and primarily acts on VSMCs via ARs. $\beta_{2}$-ARs agonists cause vasodilation and hypotension while $\alpha$ AR $\left(\alpha_{1 / 2}\right)$ agonists cause vasoconstriction (Barbato, 2009). Like PSC-ECs, PSC-VSMCs are an interesting area of research and are being used in tissue engineering strategies as well as an avenue for studying human diseases of the vascular smooth muscle (Xiang and Kobilka, 2003; Salazar et al., 2007). Little has been reported regarding GPCR function in PSC-VSMC apart from a contractile response to carbachol, and even then the muscarinic subtype was not identified (Dash et al., 2015).

\section{CXCR4 Receptor}

The SDF-CXCR4 axis plays an important role in stem cell trafficking, chemotaxis, engraftment, and therapeutic angiogenesis (Hoggatt et al., 2013). CXCR4 is required for normal vascularization of the small intestines and mesentery branching (Tachibana et al., 1998). Murine iPSC-ECs express abundant CXCR4 protein intracellularly, but not on the cell surface. When iPSC-ECs were systemically delivered, these did not home to the site of hindlimb ischemia in vivo. It was also noted that iPSC-ECs did not respond to chemotactic gradients of SDF. Overall this suggests that these cells retain an immature phenotype (Huang et al., 2013). Because GPCR proteins are typically expressed at low levels in endogenous tissues, the 
TABLE 2 | PSC-CM models of cardiac-related diseases.

\begin{tabular}{|c|c|c|c|c|c|}
\hline Condition & Cell source & Mutation & GPCRs investigated & Phenotype & References \\
\hline LEOPARD syndrome & hiPSC & $\begin{array}{l}\text { Protein tyrosine phosphatase, } \\
\text { non-receptor type } 11 \text { gene } \\
\text { (PTPN11) }\end{array}$ & Unknown & $\begin{array}{l}\text { Entigines, electrocardiographic } \\
\text { abnormalities, ocular } \\
\text { hypertelorism, pulmonary valve } \\
\text { stenosis, abnormal genitalia, } \\
\text { retardation of growth and } \\
\text { deafness }\end{array}$ & Carvajal-Vergara et al., 2010 \\
\hline $\begin{array}{l}\text { Long QT syndromes } \\
\text { (LQTS) }\end{array}$ & hiPSC & $\begin{array}{l}\text { A614V missense mutation in the } \\
\mathrm{KCNH} 2 \text { gene, c.A2987T (N996I) } \\
\mathrm{KCNH} 2 \text { mutation, KCNH2 G1681A } \\
\text { mutation }\end{array}$ & $\beta-A R$ & $\begin{array}{l}\text { Delayed repolarization of the } \\
\text { heart, arrhythmia }\end{array}$ & $\begin{array}{l}\text { Itzhaki et al., 2011; Matsa et al., } \\
\text { 2011; Bellin et al., } 2013\end{array}$ \\
\hline $\begin{array}{l}\text { Catecholaminergic } \\
\text { polymorphic ventricular } \\
\text { tachycardia (CPVT) }\end{array}$ & hiPSC & $\begin{array}{l}\text { p.F2483I mutation in ryanodine } \\
\text { receptor } 2\end{array}$ & $\beta-A R$ & Ventricular arrhythmia & $\begin{array}{l}\text { Kujala et al., 2012; Novak et al., } \\
\text { 2012; Zhang et al., } 2013\end{array}$ \\
\hline $\begin{array}{l}\text { Dilated cardiomyopathy } \\
\text { (DCM) }\end{array}$ & hiPSC & $\begin{array}{l}\text { Point mutation R173W in exon } 12 \\
\text { of troponin T2 gene }\end{array}$ & $\beta-A R$ & Non-ischemic cardiomyopathy & $\begin{array}{l}\text { Sun et al., 2012; Karakikes et al., } \\
\text { 2015; Wu et al., } 2015\end{array}$ \\
\hline $\begin{array}{l}\text { Hypertrophic } \\
\text { cardiomyopathy (HCM) }\end{array}$ & hiPSC & $\begin{array}{l}\text { Missense mutation on exon } 18 \text { of } \\
\text { the } \beta \text {-myosin heavy chain gene } \\
\text { (Arg663His) }\end{array}$ & $\beta-A R$ & $\begin{array}{l}\text { Non-ischemic cardiomyopathy, } \\
\text { enlargement of the cardiac cells }\end{array}$ & Lan et al., 2013; Han et al., 2014 \\
\hline $\begin{array}{l}\text { Arrhythmogenic right } \\
\text { ventricular } \\
\text { cardiomyopathy } \\
\text { (ARVD) }\end{array}$ & hiPSC & c.2484C>T mutation in PKP2 & $\beta-A R$ & Ventricular arrhythmia & Kim et al., 2013 \\
\hline Timothy syndrome & hiPSC & $\begin{array}{l}\text { Missense mutation in the L-type } \\
\text { calcium channel CaV1.2 }\end{array}$ & Unknown & $\begin{array}{l}\text { Heart QT prolongation, } \\
\text { arrhythmias, structural cardiac } \\
\text { defects, webbing of fingers and } \\
\text { toes and autism spectrum } \\
\text { disorders }\end{array}$ & $\begin{array}{l}\text { Yazawa et al., 2011; Song et al., } \\
2015\end{array}$ \\
\hline Barth syndrome & hiPSC & Mutation of gene encoding tafazzin & Unknown & $\begin{array}{l}\text { Cardiomyopathy, neutropenia, } \\
\text { underdeveloped skeletal } \\
\text { musculature and muscle } \\
\text { weakness, growth delay, } \\
\text { cardiolipin abnormalities }\end{array}$ & Wang et al., 2014 \\
\hline $\begin{array}{l}\text { Diabetic } \\
\text { cardiomyopathy }\end{array}$ & hiPSC & $\mathrm{N} / \mathrm{A}$ & Endothelin, $\beta$-AR & Cardiomyopathy & Drawnel et al., 2014 \\
\hline $\begin{array}{l}\text { Duchenne muscular } \\
\text { dystrophy (DMD) }\end{array}$ & hiPSC & $\begin{array}{l}\text { Mutation in DMD gene encoding } \\
\text { dystrophin }\end{array}$ & Unknown & $\begin{array}{l}\text { Muscle degeneration and } \\
\text { premature death }\end{array}$ & Lin et al., 2015 \\
\hline Down's syndrome & hESC & Trisomy 21 & $\beta-A R$ & $\begin{array}{l}\text { Delayed physical growth, facial } \\
\text { features, and intellectual disability }\end{array}$ & Bosman et al., 2015 \\
\hline
\end{tabular}

use of proteomic profiling approaches for identifying further endothelial-specific GPCRs proves problematic.

\section{Angiotensin Receptor}

Ang II stimulates VSMC contraction and aldosterone release with consequent sodium retention. It also stimulates the production of ECM proteins and is pro-inflammatory (Wollert and Drexler, 1999). Ang II is the main mediator of this pathway and signals primarily through the $\mathrm{AT}_{1}$ receptor (Touyz and Schiffrin, 2000). $\mathrm{AT}_{1}$ receptors are upregulated in response to hypertensive rats and hypertrophic stimuli (Suzuki et al., 1993). In contrast, they are down-regulated in systolic heart failure (Rogg et al., 1996). Overexpressing $\mathrm{AT}_{1 \mathrm{~A}}$ in mice resulted in hypertrophy and fibrosis of myocardial tissue (collagen deposition; Paradis et al., 2000). $\mathrm{AT}_{1 \mathrm{~A}}$ deficient mice, however, were more resistant to the effects of myocardial ischemia with less ventricular dilatation and fibrosis and a better recovery in LV function 4 weeks after infarction (Harada et al., 1999). To date, the effect of Angiotensin receptors and stem cells has only been investigated in mice. $\mathrm{AT}_{1} \mathrm{R}$ stimulation has been found to enhance not only the proliferation but also the differentiation of undifferentiated pluripotent stem cells into mesodermal progenitor cells (Ishizuka et al., 2012).

\section{Endothelin Receptor}

The endothelin pathway also has a regulatory role in hPSCECs. Differentiation of hESC into endothelial cells (hESC-ECs) can be a potential source of cells and endothelial factors for ischemic diseases by supporting angiogenesis and vasculogenesis (Burdon et al., 1999; Lesman et al., 2010). Protocols for new ECs from hPSC generated cells with high initial clonal proliferative potential with self-repopulating activity and in vivo vesselforming ability have been devised (Ingram et al., 2004; Földes et al., 2010; James et al., 2010). However, a number of differences between hPSC-derived cells and adult ECs have been noted. For example, we found that hESC-EC failed to release the GPCR ligand endothelin-1 (ET-1) at levels comparable to human aortic ECs or to blood outgrowth ECs (Reed et al., 2014). However, in a separate study it was demonstrated that hiPSC-EC were able 
TABLE 3 | GPCRs present in human endothelial cells.

\begin{tabular}{|c|c|c|c|}
\hline GPCR & Ligand & Role & References \\
\hline $\begin{array}{l}\text { Platelet } \\
\text { activating } \\
\text { factor receptor } \\
\text { (PAF) }\end{array}$ & $\begin{array}{l}\text { Platelet } \\
\text { activating } \\
\text { factor (PAF) }\end{array}$ & $\begin{array}{l}\text { Vascular permeability, } \\
\text { increasing gap } \\
\text { formation between } \\
\text { endothelial cells }\end{array}$ & $\begin{array}{l}\text { Handley et al., } \\
1984\end{array}$ \\
\hline $\begin{array}{l}\text { Histamine } \\
\text { receptor }(\mathrm{H})\end{array}$ & Histamine & Vascular permeability & Bakker et al., 2002 \\
\hline $\begin{array}{l}\text { Protease } \\
\text { activated } \\
\text { receptor (PAR) }\end{array}$ & Thrombin & $\begin{array}{l}\text { Vascular permeability, } \\
\text { cellular differentiation, } \\
\text { migration, and } \\
\text { proliferation of VSMC, } \\
\text { angiogenesis and } \\
\text { vascular development }\end{array}$ & $\begin{array}{l}\text { Patterson et al., } \\
2001\end{array}$ \\
\hline S1PR & S1P & $\begin{array}{l}\text { Stabilization of the } \\
\text { endothelial barrier }\end{array}$ & English et al., 1999 \\
\hline CXCR4 & SDF & Chemotaxis & $\begin{array}{l}\text { Hoggatt et al., } \\
2013\end{array}$ \\
\hline AT & Ang & $\begin{array}{l}\text { Vasodilation, growth } \\
\text { inhibition, vascular tone }\end{array}$ & $\begin{array}{l}\text { Pueyo and Michel, } \\
1997\end{array}$ \\
\hline ET & ET-1 & $\begin{array}{l}\text { Vasoconstriction, } \\
\text { vascular homeostasis }\end{array}$ & $\begin{array}{l}\text { Kedzierski and } \\
\text { Yanagisawa, } 2001\end{array}$ \\
\hline
\end{tabular}

to upregulate ET-1 expressionin response to atheroprone flow (Adams et al., 2013).

\section{Disease Modeling with PSC-ECs and PSC-VSMC}

In contrast to myocytes, limited studies using disease models in EC and VSMC are available. They have been used for vascular repair: the first model using ESC-ECs has recently been evaluated in myocardial infarction and hindlimb ischemia as a therapeutic option to promote angiogenesis and neovascularization (Cho et al., 2007; Yu et al., 2009). iPSC-ECs derived from dietinduced obese mice exhibits endothelial dysfunction and may not be suitable for therapeutic transplantation in a hindlimb ischemia model. Furthermore, the administration of statins reversed endothelial dysfunction both in vitro and in vivo $(\mathrm{Gu}$ et al., 2015).

Recently, hiPSC lines were differentiated from patients with supravalvular aortic stenosis (William's syndrome). The VSMCs displayed a blunted maturation profile with fewer organized smooth muscle $\alpha$-actin filament bundles networks and also had a higher proliferation rate (a hallmark of the disease). Reversion to a wild type phenotype was achieved by the addition of recombinant elastin protein or enhancing small GTPase RhoA signaling (Ge et al., 2012). In addition, hiPSC-VSMCs have been derived from patients with Hutchinson-Gilford progeria syndrome (HGP), a disease carrying a lamin A mutation and increased progerin levels, leading to premature aging and early mortality by myocardial infarction/stroke. The differentiated VSMCs contained high levels of progerin and also exhibited a new phenotype, calponin-1 staining inclusion bodies in the cytoplasm. Additionally, the VSMCs had nuclear abnormalities and increased DNA damage compared to controls (Zhang et al., 2011). To date, the GPCR related signaling of these human diseases have not been clarified.

\section{SUMMARY: FOCUSSED TARGETING OF GPCR SIGNALING IN HUMAN CARDIOVASCULAR SYSTEM}

hPSCs show potential as a platform for both studying disease as well as an autologous source of cells for possible transplantation therapy (Lee et al., 2010a). Particularly for cardiomyocytes, where adult cells are difficult to manipulate in culture and options for cell lines are severely limited, the advent of disease-specific hiPSC-CM represents a great step forward. Differentiation methods are improving in efficiency and reproducibility. However, models should never be accepted uncritically, and a more sophisticated dissection of their fidelity has begun to appear. One major limitation is the greater resemblance of hPSC$\mathrm{CM}$ to immature cardiomyocytes, although this may also be a reflection of the general differences induced by $2 \mathrm{D}$ cell culture. This could present a problem for models of late onset diseases. A wide array of approaches are being undertaken to improve maturation of these cells in an attempt to provide better models of disease. These include; prolonged time in culture (Ivashchenko et al., 2013), application of triiodothyronine (T3; Lee et al., 2010b; Ivashchenko et al., 2013; Yang et al., 2014; Ribeiro et al., 2015), manipulation of culture substrate (Rao et al., 2013; Tallawi et al., 2015), 3 D culture (Schaaf et al., 2011) and long term electrical pacing (Lieu et al., 2013; Hirt et al., 2014). hPSC-EC also display an immature phenotype (Huang et al., 2013), which still requires further investigation.

Another limitation is the use of correct controls, particularly for disease models. Obtaining control material from familial relatives of patients can prove difficult, which makes drawing solid conclusions from these disease models problematic. Gene editing technology approaches, such as the clustered regularly interspaced short palindromic repeats (CRISPR) system and zinc finger nucleases(ZFN) have arisen as useful tools to generate control lines on the same genetic background as the diseased cells. Alternatively, recreation of disease causing mutations in wild type cell lines using these technologies is an option and will allow multiple mutations to be compared in a more controlled manner. Additionally, identifying pharmacologicallyrelevant phenotypes in these models is important. It also remains to be determined whether monogenic disease and pharmacological models are comparable in cardiovascular diseases. The expected phenotype is not always present, for example in cardiac hypertrophy (Földes et al., 2014), which may be a limitation of the in vitro models. Modeling conditions with a broader tissue based-phenotype including scar formation, fibrosis and tissue disarray are also not possible using hPSC$\mathrm{CM}$ in $2 \mathrm{D}$ culture, although the reconstruction of $3 \mathrm{D}$ tissue models may allow advances in this area. In particular, a greater understanding of GPCR signaling in hPSC-CM is needed to ensure accurate disease modeling and to determine suitability for use in pharmaceutical compound screening. More focussed investigation into the expression profile and functional characterization of GPCRs in PSC-derived cardiovascular cells is required to establish their resemblance to in vivo models. 


\section{AUTHOR CONTRIBUTIONS}

$\mathrm{ND}, \mathrm{NH}, \mathrm{RJ}, \mathrm{GF}$ contributed to the conception of the review and wrote the manuscript. SH critical revised and final approved the review.

\section{REFERENCES}

Adams, W. J., Zhang, Y., Cloutier, J., Kuchimanchi, P., Newton, G., Sehrawat, S., et al. (2013). Functional vascular endothelium derived from human induced pluripotent stem cells. Stem Cell Reports 1, 105-113. doi: 10.1016/j.stemcr.2013.06.007

Aggarwal, P., Turner, A., Matter, A., Kattman, S. J., Stoddard, A., Lorier, R., et al. (2014). RNA expression profiling of human iPSC-derived cardiomyocytes in a cardiac hypertrophy model. PLoS ONE 9:e108051. doi: 10.1371/journal.pone.0108051

Akhter, S. A., Milano, C. A., Shotwell, K. F., Cho, M. C., Rockman, H. A., Lefkowitz, R. J., et al. (1997). Transgenic mice with cardiac overexpression of alpha1B-adrenergic receptors. In vivo alpha1-adrenergic receptor-mediated regulation of beta-adrenergic signaling. J. Biol. Chem. 272, 21253-21259. doi: $10.1074 /$ jbc. 272.34.21253

Ali, N. N., Xu, X., Brito-Martins, M., Poole-Wilson, P. A., Harding, S. E., and Fuller, S. J. (2004). Beta-adrenoceptor subtype dependence of chronotropy in mouse embryonic stem cell-derived cardiomyocytes. Basic Res. Cardiol. 99, 382-391. doi: 10.1007/s00395-004-0484-5

Ancellin, N., and Hla, T. (1999). Differential pharmacological properties and signal transduction of the sphingosine 1-phosphate receptors EDG-1, EDG-3, and EDG-5. J. Biol. Chem. 274, 18997-19002. doi: 10.1074/jbc.274.27.18997

Asano, K., Bohlmeyer, T. J., Westcott, J. Y., Zisman, L., Kinugawa, K., Good, M., et al. (2002). Altered expression of endothelin receptors in failing human left ventricles. J. Mol. Cell. Cardiol. 34, 833-846. doi: 10.1006/jmcc.2002.2022

Ashley, E. A., Powers, J., Chen, M., Kundu, R., Finsterbach, T., Caffarelli, A., et al. (2005). The endogenous peptide apelin potently improves cardiac contractility and reduces cardiac loading in vivo. Cardiovasc. Res. 65, 73-82. doi: 10.1016/j.cardiores.2004.08.018

Bajpai, V. K., Mistriotis, P., Loh, Y. H., Daley, G. Q., and Andreadis, S. T. (2012). Functional vascular smooth muscle cells derived from human induced pluripotent stem cells via mesenchymal stem cell intermediates. Cardiovasc. Res. 96, 391-400. doi: 10.1093/cvr/cvs253

Bakker, R. A., Timmerman, H., and Leurs, R. (2002). Histamine receptors: specific ligands, receptor biochemistry, and signal transduction. Clin. Allergy Immunol. $17,27-64$.

Barbato, E. (2009). Role of adrenergic receptors in human coronary vasomotion. Heart 95, 603-608. doi: 10.1136/hrt.2008.150888

Batenburg, W. W., Garrelds, I. M., Bernasconi, C. C., Juillerat-Jeanneret, L., van Kats, J. P., Saxena, P. R., et al. (2004). Angiotensin II type 2 receptor-mediated vasodilation in human coronary microarteries. Circulation 109, 2296-2301. doi: 10.1161/01.CIR.0000128696.12245.57

Bellin, M., Casini, S., Davis, R. P., D’Aniello, C., Haas, J., Ward-van, O. D., et al. (2013). Isogenic human pluripotent stem cell pairs reveal the role of a KCNH2 mutation in long-QT syndrome. EMBO J. 32, 3161-3175. doi: 10.1038/emboj.2013.240

Berry, M. F., Pirolli, T. J., Jayasankar, V., Burdick, J., Morine, K. J., Gardner, T. J., et al. (2004). Apelin has in vivo inotropic effects on normal and failing hearts. Circulation 110, II187-II193. doi: 10.1161/01.CIR.0000138382.57325.5c

Bosman, A., Letourneau, A., Sartiani, L., Del, L. M., Ronzoni, F., Kuziakiv, R., et al. (2015). Perturbations of heart development and function in cardiomyocytes from human embryonic stem cells with trisomy 21. Stem Cells 33, 1434-1446. doi: $10.1002 /$ stem. 1961

Brito-Martins, M., Harding, S. E., and Ali, N. N. (2008). beta(1)- and beta(2)adrenoceptor responses in cardiomyocytes derived from human embryonic stem cells: comparison with failing and non-failing adult human heart. Br. J. Pharmacol. 153, 751-759. doi: 10.1038/sj.bjp.0707619

Brückner, R., Mügge, A., and Scholz, H. (1985). Existence and functional role of alpha 1-adrenoceptors in the mammalian heart. J. Mol. Cell. Cardiol. 17, 639-645. doi: 10.1016/S0022-2828(85)80063-8

\section{FUNDING}

This paper was supported by the British Heart Foundation RM/13/1/30157 and Fondation Leducq Shapeheart Network 5 CVD 03.

Buikema, J. W., Mady, A. S., Mittal, N. V., Atmanli, A., Caron, L., Doevendans, P. A., et al. (2013a). Wnt/beta-catenin signaling directs the regional expansion of first and second heart field-derived ventricular cardiomyocytes. Development 140, 4165-4176. doi: 10.1242/dev.099325

Buikema, J. W., Zwetsloot, P. P., Doevendans, P. A., Sluijter, J. P., and Domian, I. J. (2013b). Expanding mouse ventricular cardiomyocytes through GSK-3 inhibition. Curr. Protoc. Cell Biol. 61, 23. doi: 10.1002/0471143030.cb2309s61

Bupha-Intr, T., Haizlip, K. M., and Janssen, P. M. (2012). Role of endothelin in the induction of cardiac hypertrophy in vitro. PLoS ONE 7:e43179. doi: 10.1371/journal.pone.0043179

Burdon, T., Stracey, C., Chambers, I., Nichols, J., and Smith, A. (1999). Suppression of SHP-2 and ERK signalling promotes self-renewal of mouse embryonic stem cells. Dev. Biol. 210, 30-43. doi: 10.1006/dbio.1999.9265

Cai, L., Ye, Z., Zhou, B. Y., Mali, P., Zhou, C., and Cheng, L. (2007). Promoting human embryonic stem cell renewal or differentiation by modulating Wnt signal and culture conditions. Cell Res. 17, 62-72. doi: 10.1038/sj.cr.7310138

Callihan, P., Mumaw, J., Machacek, D. W., Stice, S. L., and Hooks, S. B. (2011). Regulation of stem cell pluripotency and differentiation by G protein coupled receptors. Pharmacol. Ther. 129, 290-306. doi: 10.1016/j.pharmthera.2010.10.007

Carlson, C., Koonce, C., Aoyama, N., Einhorn, S., Fiene, S., Thompson, A., et al. (2013). Phenotypic screening with human iPS cell-derived cardiomyocytes: HTS-compatible assays for interrogating cardiac hypertrophy. J. Biomol. Screen. 18, 1203-1211. doi: 10.1177/1087057113500812

Carvajal-Vergara, X., Sevilla, A., D’Souza, S. L., Ang, Y. S., Schaniel, C., Lee, D. F., et al. (2010). Patient-specific induced pluripotent stem-cell-derived models of LEOPARD syndrome. Nature 465, 808-812. doi: 10.1038/nature09005

Cavalli, A., Lattion, A. L., Hummler, E., Nenniger, M., Pedrazzini, T., Aubert, J. F., et al. (1997). Decreased blood pressure response in mice deficient of the alpha1b-adrenergic receptor. Proc. Natl. Acad. Sci. U.S.A. 94, 11589-11594. doi: 10.1073/pnas.94.21.11589

Chen, A., Ting, S., Seow, J., Reuveny, S., and Oh, S. (2014). Considerations in designing systems for large scale production of human cardiomyocytes from pluripotent stem cells. Stem Cell Res. Ther. 5, 12. doi: 10.1186/scrt401

Chen, Y., Amende, I., Hampton, T. G., Yang, Y., Ke, Q., Min, J. Y., et al. (2006). Vascular endothelial growth factor promotes cardiomyocyte differentiation of embryonic stem cells. Am. J. Physiol. Heart Circ. Physiol. 291, H1653-H1658. doi: 10.1152/ajpheart.00363.2005

Chng, S. C., Ho, L., Tian, J., and Reversade, B. (2013). ELABELA: a hormone essential for heart development signals via the apelin receptor. Dev. Cell 27, 672-680. doi: 10.1016/j.devcel.2013.11.002

Cho, S. W., Moon, S. H., Lee, S. H., Kang, S. W., Kim, J., Lim, J. M., et al. (2007). Improvement of postnatal neovascularization by human embryonic stem cell derived endothelial-like cell transplantation in a mouse model of hindlimb ischemia. Circulation 116, 2409-2419. doi: 10.1161/CIRCULATIONAHA.106.687038

Chruscinski, A. J., Rohrer, D. K., Schauble, E., Desai, K. H., Bernstein, D., and Kobilka, B. K. (1999). Targeted disruption of the beta2 adrenergic receptor gene. J. Biol. Chem. 274, 16694-16700. doi: 10.1074/jbc.274.24.16694

Concas, V., Laurent, S., Brisac, A. M., Perret, C., and Safar, M. (1989). Endothelin has potent direct inotropic and chronotropic effects in cultured heart cells. J. Hypertens. Suppl. 7, S96-S97. doi: 10.1097/00004872-19890007600044

Daaka, Y., Luttrell, L. M., and Lefkowitz, R. J. (1997). Switching of the coupling of the beta2-adrenergic receptor to different $\mathrm{G}$ proteins by protein kinase A. Nature 390, 88-91. doi: 10.1038/36362

Dambrot, C., Braam, S. R., Tertoolen, L. G., Birket, M., Atsma, D. E., and Mummery, C. L. (2014). Serum supplemented culture medium masks hypertrophic phenotypes in human pluripotent stem cell derived cardiomyocytes. J. Cell. Mol. Med. 18, 1509-1518. doi: 10.1111/jcmm.12356 
Daneman, R., Agalliu, D., Zhou, L., Kuhnert, F., Kuo, C. J., and Barres, B. A. (2009). Wnt/beta-catenin signaling is required for CNS, but not non-CNS, angiogenesis. Proc. Natl. Acad. Sci. U.S.A. 106, 641-646. doi: 10.1073/pnas.0805165106

D’Aniello, C., Fiorenzano, A., Iaconis, S., Liguori, G. L., Andolfi, G., Cobellis, G., et al. (2013). The G-protein-coupled receptor APJ is expressed in the second heart field and regulates Cerberus-Baf60c axis in embryonic stem cell cardiomyogenesis. Cardiovasc. Res. 100, 95-104. doi: 10.1093/cvr/cvt166

Dash, B. C., Jiang, Z., Suh, C., and Qyang, Y. (2015). Induced pluripotent stem cell-derived vascular smooth muscle cells: methods and application. Biochem. J. 465, 185-194. doi: 10.1042/BJ20141078

de Gasparo, G. M., Catt, K. J., Inagami, T., Wright, J. W., and Unger, T. (2000). International union of pharmacology. XXIII. The angiotensin II receptors. Pharmacol. Rev. 52, 415-472.

Dottori, M., Leung, J., Turnley, A. M., and Pébay, A. (2008). Lysophosphatidic acid inhibits neuronal differentiation of neural stem/progenitor cells derived from human embryonic stem cells. Stem Cells 26, 1146-1154. doi: 10.1634/stemcells.2007-1118

Dravid, G., Ye, Z., Hammond, H., Chen, G., Pyle, A., Donovan, P., et al. (2005). Defining the role of Wnt/beta-catenin signaling in the survival, proliferation, and self-renewal of human embryonic stem cells. Stem Cells 23, 1489-1501. doi: 10.1634/stemcells.2005-0034

Drawnel, F. M., Boccardo, S., Prummer, M., Delobel, F., Graff, A., Weber, M., et al. (2014). Disease modeling and phenotypic drug screening for diabetic cardiomyopathy using human induced pluripotent stem cells. Cell Rep. 9, 810-821. doi: 10.1016/j.celrep.2014.09.055

Egger-Adam, D., and Katanaev, V. L. (2008). Trimeric G protein-dependent signaling by Frizzled receptors in animal development. Front. Biosci. 13, 4740-4755. doi: 10.2741/3036

Engelhardt, S., Hein, L., Wiesmann, F., and Lohse, M. J. (1999). Progressive hypertrophy and heart failure in betal-adrenergic receptor transgenic mice. Proc. Natl. Acad. Sci. U.S.A. 96, 7059-7064. doi: 10.1073/pnas.96.12.7059

English, D., Kovala, A. T., Welch, Z., Harvey, K. A., Siddiqui, R. A., Brindley, D. N., et al. (1999). Induction of endothelial cell chemotaxis by sphingosine 1-phosphate and stabilization of endothelial monolayer barrier function by lysophosphatidic acid, potential mediators of hematopoietic angiogenesis. J. Hematother. Stem Cell Res. 8, 627-634. doi: 10.1089/1525816993 19795

Evseenko, D., Zhu, Y., Schenke-Layland, K., Kuo, J., Latour, B., Ge, S., et al. (2010). Mapping the first stages of mesoderm commitment during differentiation of human embryonic stem cells. Proc. Natl. Acad. Sci. U.S.A. 107, 13742-13747. doi: $10.1073 /$ pnas.1002077107

Exton, J. H. (1985). Mechanisms involved in alpha-adrenergic phenomena. Am. J. Physiol. 248, E633-E647.

Faherty, S., Fitzgerald, A., Keohan, M., and Quinlan, L. R. (2007). Self-renewal and differentiation of mouse embryonic stem cells as measured by Oct 4 expression: the role of the cAMP/PKA pathway. In Vitro Cell Dev. Biol. Anim. 43, 37-47. doi: 10.1007/s11626-006-9001-5

Földes, G., Harding, S. E., and Ali, N. N. (2008). Cardiomyocytes from embryonic stem cells: towards human therapy. Expert. Opin. Biol. Ther. 8, 1473-1483. doi: 10.1517/14712598.8.10.1473

Földes, G., Liu, A., Badiger, R., Paul-Clark, M., Moreno, L., Lendvai, Z., et al. (2010). Innate immunity in human embryonic stem cells: comparison with adult human endothelial cells. PLOS ONE 5:e10501. doi: 10.1371/journal.pone.0010501

Földes, G., Matsa, E., Kriston-Vizi, J., Leja, T., Amisten, S., Kolker, L., et al. (2014). Aberrant alpha-adrenergic hypertrophic response in cardiomyocytes from human induced pluripotent cells. Stem Cell Reports 3, 905-914. doi: 10.1016/j.stemcr.2014.09.002

Földes, G., Mioulane, M., Wright, J. S., Liu, A. Q., Novak, P., Merkely, B., et al. (2011). Modulation of human embryonic stem cell-derived cardiomyocyte growth: a testbed for studying human cardiac hypertrophy? J. Mol. Cell. Cardiol. 50, 367-376. doi: 10.1016/j.yjmcc.2010.10.029

Foord, S. M., Bonner, T. I., Neubig, R. R., Rosser, E. M., Pin, J. P., Davenport, A. P., et al. (2005). International Union of Pharmacology. XLVI. G protein-coupled receptor list. Pharmacol. Rev. 57, 279-288. doi: 10.1124/pr.57.2.5

Fredriksson, R., Lagerstrom, M. C., Lundin, L. G., and Schioth, H. B. (2003). The G-protein-coupled receptors in the human genome form five main families.
Phylogenetic analysis, paralogon groups, and fingerprints. Mol. Pharmacol. 63, 1256-1272. doi: 10.1124/mol.63.6.1256

Garcia, J. G., Liu, F., Verin, A. D., Birukova, A., Dechert, M. A., Gerthoffer, W. T., et al. (2001). Sphingosine 1-phosphate promotes endothelial cell barrier integrity by Edg-dependent cytoskeletal rearrangement. J. Clin. Invest 108, 689-701. doi: 10.1172/JCI12450

Gauthier, C., Tavernier, G., Charpentier, F., Langin, D., and Le, M. H. (1996). Functional beta3-adrenoceptor in the human heart. J. Clin. Invest. 98, 556-562. doi: 10.1172/JCI118823

Ge, X., Ren, Y., Bartulos, O., Lee, M. Y., Yue, Z., Kim, K. Y., et al. (2012). Modeling supravalvular aortic stenosis syndrome with human induced pluripotent stem cells. Circulation 126, 1695-1704. doi: 10.1161/CIRCULATIONAHA.112.116996

Gessert, S., and Kühl, M. (2010). The multiple phases and faces of wnt signaling during cardiac differentiation and development. Circ. Res. 107, 186-199. doi: 10.1161/CIRCRESAHA.110.221531

Gether, U., Asmar, F., Meinild, A. K., and Rasmussen, S. G. (2002). Structural basis for activation of G-protein-coupled receptors. Pharmacol. Toxicol. 91, 304-312. doi: 10.1034/j.1600-0773.2002.910607.x

Gloriam, D. E., Fredriksson, R., and Schiöth, H. B. (2007). The G protein-coupled receptor subset of the rat genome. BMC. Genomics 8:338. doi: 10.1186/14712164-8-338

Goldman, O., Feraud, O., Boyer-Di, P. J., Driancourt, C., Clay, D., Le BousseKerdiles, M. C., et al. (2009). A boost of BMP4 accelerates the commitment of human embryonic stem cells to the endothelial lineage. Stem Cells 27, 1750-1759. doi: 10.1002/stem.100

Gong, H., Adamson, D. L., Ranu, H. K., Koch, W. J., Heubach, J. F., Ravens, U., et al. (2000). The effect of Gi-protein inactivation on basal, and beta(1)and beta(2)AR-stimulated contraction of myocytes from transgenic mice overexpressing the beta(2)-adrenoceptor. Br. J. Pharmacol. 131, 594-600. doi: 10.1038/sj.bjp.0703591

Griffin, C. T., Srinivasan, Y., Zheng, Y. W., Huang, W., and Coughlin, S. R. (2001). A role for thrombin receptor signaling in endothelial cells during embryonic development. Science 293, 1666-1670. doi: 10.1126/science.10 61259

Gu, M., Mordwinkin, N. M., Kooreman, N. G., Lee, J., Wu, H., Hu, S., et al. (2015). Pravastatin reverses obesity-induced dysfunction of induced pluripotent stem cell-derived endothelial cells via a nitric oxide-dependent mechanism. Eur. Heart J. 36, 806-816. doi: 10.1093/eurheartj/ehu411

Guo, Y., Hangoc, G., Bian, H., Pelus, L. M., and Broxmeyer, H. E. (2005). SDF$1 /$ CXCL12 enhances survival and chemotaxis of murine embryonic stem cells and production of primitive and definitive hematopoietic progenitor cells. Stem Cells 23, 1324-1332. doi: 10.1634/stemcells.2005-0085

Han, L., Li, Y., Tchao, J., Kaplan, A. D., Lin, B., Li, Y., et al. (2014). Study familial hypertrophic cardiomyopathy using patient-specific induced pluripotent stem cells. Cardiovasc. Res. 104, 258-269. doi: 10.1093/cvr/cvu205

Handley, D. A., Arbeeny, C. M., Lee, M. L., Van Valen, R. G., and Saunders, R. N. (1984). Effect of platelet activating factor on endothelial permeability to plasma macromolecules. Immunopharmacology 8, 137-142. doi: 10.1016/01623109(84)90017-1

Harada, K., Sugaya, T., Murakami, K., Yazaki, Y., and Komuro, I. (1999). Angiotensin II type 1A receptor knockout mice display less left ventricular remodeling and improved survival after myocardial infarction. Circulation 100, 2093-2099. doi: 10.1161/01.CIR.100.20.2093

Headrick, J. P., Ashton, K. J., Rose'meyer, R. B., and Peart, J. N. (2013). Cardiovascular adenosine receptors: expression, actions and interactions. Pharmacol. Ther. 140, 92-111. doi: 10.1016/j.pharmthera.2013.06.002

Higuchi, S., Ohtsu, H., Suzuki, H., Shirai, H., Frank, G. D., and Eguchi, S. (2007). Angiotensin II signal transduction through the AT1 receptor: novel insights into mechanisms and pathophysiology. Clin. Sci. (Lond.) 112, 417-428. doi: 10.1042/CS20060342

Hirt, M. N., Boeddinghaus, J., Mitchell, A., Schaaf, S., Börnchen, C., Müller, C., et al. (2014). Functional improvement and maturation of rat and human engineered heart tissue by chronic electrical stimulation. J. Mol. Cell. Cardiol. 74, 151-161. doi: 10.1016/j.yjmcc.2014.05.009

Hoggatt, J., Mohammad, K. S., Singh, P., Hoggatt, A. F., Chitteti, B. R., Speth, J. M., et al. (2013). Differential stem- and progenitor-cell trafficking by prostaglandin E2. Nature 495, 365-369. doi: 10.1038/nature11929 
Hou, P., Li, Y., Zhang, X., Liu, C., Guan, J., Li, H., et al. (2013). Pluripotent stem cells induced from mouse somatic cells by small-molecule compounds. Science 341, 651-654. doi: 10.1126/science. 1239278

Huang, H. C., and Klein, P. S. (2004). The Frizzled family: receptors for multiple signal transduction pathways. Genome Biol. 5, 234. doi: 10.1186/gb-2004-5-7234

Huang, N. F., Dewi, R. E., Okogbaa, J., Lee, J. C., Jalilrufaihah, A., Heilshorn, S. C., et al. (2013). Chemotaxis of human induced pluripotent stem cell-derived endothelial cells. Am. J. Transl. Res. 5, 510-520.

Hunt, S. A., Abraham, W. T., Chin, M. H., Feldman, A. M., Francis, G. S., Ganiats, T. G., et al. (2009). 2009 Focused update incorporated into the ACC/AHA 2005 guidelines for the diagnosis and management of heart failure in adults a report of the American College of Cardiology Foundation/American Heart Association Task Force on practice guidelines developed in collaboration with the international society for heart and lung transplantation. J. Am. Coll. Cardiol. 53, e1-e90. doi: 10.1016/j.jacc.2008.11.013

Ingram, D. A., Mead, L. E., Tanaka, H., Meade, V., Fenoglio, A., Mortell, K., et al. (2004). Identification of a novel hierarchy of endothelial progenitor cells using human peripheral and umbilical cord blood. Blood 104, 2752-2760. doi: 10.1182/blood-2004-04-1396

Inniss, K., and Moore, H. (2006). Mediation of apoptosis and proliferation of human embryonic stem cells by sphingosine-1-phosphate. Stem Cells Dev. 15, 789-796. doi: $10.1089 / \mathrm{scd} .2006 .15 .789$

Ishizuka, T., Goshima, H., Ozawa, A., and Watanabe, Y. (2012). Effect of angiotensin II on proliferation and differentiation of mouse induced pluripotent stem cells into mesodermal progenitor cells. Biochem. Biophys. Res. Commun. 420, 148-155. doi: 10.1016/j.bbrc.2012.02.132

Itzhaki, I., Maizels, L., Huber, I., Zwi-Dantsis, L., Caspi, O., Winterstern, A., et al. (2011). Modelling the long QT syndrome with induced pluripotent stem cells. Nature 471, 225-229. doi: 10.1038/nature09747

Ivashchenko, C. Y., Pipes, G. C., Lozinskaya, I. M., Lin, Z., Xiaoping, X., Needle, S., et al. (2013). Human-induced pluripotent stem cell-derived cardiomyocytes exhibit temporal changes in phenotype. Am. J. Physiol. Heart Circ. Physiol. 305, H913-H922. doi: 10.1152/ajpheart.00819.2012

James, D., Nam, H. S., Seandel, M., Nolan, D., Janovitz, T., Tomishima, M., et al. (2010). Expansion and maintenance of human embryonic stem cell-derived endothelial cells by TGFbeta inhibition is Id1 dependent. Nat. Biotechnol. 28, 161-166. doi: 10.1038/nbt.1605

Jeter, J. R. Jr., and Cameron, I. L. (1971). Cell proliferation patterns during cytodifferentiation in embryonic chick tissues: liver, heart and erythrocytes. J. Embryol. Exp. Morphol. 25, 405-422.

Jiang, S., Fu, Y., Williams, J., Wood, J., Pandarinathan, L., Avraham, S., et al. (2007). Expression and function of cannabinoid receptors CB1 and CB2 and their cognate cannabinoid ligands in murine embryonic stem cells. PLoS ONE 2:e641. doi: 10.1371/journal.pone.0000641

Kang, H., Kim, K. H., Lim, J., Kim, Y. S., Heo, J., Choi, J., et al. (2015). The therapeutic effects of human mesenchymal stem cells primed with sphingosine1 phosphate on pulmonary artery hypertension. Stem Cells Dev. 24, 1658-1671. doi: $10.1089 / \mathrm{scd} .2014 .0496$

Karakikes, I., Stillitano, F., Nonnenmacher, M., Tzimas, C., Sanoudou, D., Termglinchan, V., et al. (2015). Correction of human phospholamban R14del mutation associated with cardiomyopathy using targeted nucleases and combination therapy. Nat. Commun. 6, 6955. doi: 10.1038/ncomm s7955

Karamariti, E., Margariti, A., Winkler, B., Wang, X., Hong, X., Baban, D., et al. (2013). Smooth muscle cells differentiated from reprogrammed embryonic lung fibroblasts through DKK3 signaling are potent for tissue engineering of vascular grafts. Circ. Res. 112, 1433-1443. doi: 10.1161/CIRCRESAHA.111.300415

Katanaev, V. L., Ponzielli, R., Sémériva, M., and Tomlinson, A. (2005). Trimeric $\mathrm{G}$ protein-dependent frizzled signaling in Drosophila. Cell 120, 111-122. doi: 10.1016/j.cell.2004.11.014

Kataoka, H., Hamilton, J. R., McKemy, D. D., Camerer, E., Zheng, Y. W., Cheng, A., et al. (2003). Protease-activated receptors 1 and 4 mediate thrombin signaling in endothelial cells. Blood 102, 3224-3231. doi: 10.1182/blood-2003-04-1130

Kedzierski, R. M., and Yanagisawa, M. (2001). Endothelin system: the doubleedged sword in health and disease. Annu. Rev. Pharmacol. Toxicol. 41, 851-876. doi: 10.1146/annurev.pharmtox.41.1.851
Kim, C., Wong, J., Wen, J., Wang, S., Wang, C., Spiering, S., et al. (2013). Studying arrhythmogenic right ventricular dysplasia with patient-specific iPSCs. Nature 494, 105-110. doi: 10.1038/nature11799

Klipp, E., and Liebermeister, W. (2006). Mathematical modeling of intracellular signaling pathways. BMC. Neurosci. 7(Suppl. 1):S10. doi: 10.1186/1471-2202-7s1-s10

Kobayashi, N. R., Hawes, S. M., Crook, J. M., and Pébay, A. (2010). G-protein coupled receptors in stem cell self-renewal and differentiation. Stem Cell Rev. 6, 351-366. doi: 10.1007/s12015-010-9167-9

Kober, L., Torp-Pedersen, C., Carlsen, J. E., Bagger, H., Eliasen, P., Lyngborg, K., et al. (1995). A clinical trial of the angiotensin-converting-enzyme inhibitor trandolapril in patients with left ventricular dysfunction after myocardial infarction. Trandolapril Cardiac Evaluation (TRACE) study group. N. Engl. J. Med. 333, 1670-1676. doi: 10.1056/NEJM199512213332503

Kohout, T. A., Takaoka, H., McDonald, P. H., Perry, S. J., Mao, L., Lefkowitz, R. J., et al. (2001). Augmentation of cardiac contractility mediated by the human beta(3)-adrenergic receptor overexpressed in the hearts of transgenic mice. Circulation 104, 2485-2491. doi: 10.1161/hc4501.098933

Korkaya, H., Paulson, A., Charafe-Jauffret, E., Ginestier, C., Brown, M., Dutcher, J., et al. (2009). Regulation of mammary stem/progenitor cells by PTEN/Akt/betacatenin signaling. PLoS. Biol. 7:e1000121. doi: 10.1371/journal.pbio.10 00121

Kristiansen, K. (2004). Molecular mechanisms of ligand binding, signaling, and regulation within the superfamily of G-protein-coupled receptors: molecular modeling and mutagenesis approaches to receptor structure and function. Pharmacol. Ther. 103, 21-80. doi: 10.1016/j.pharmthera.2004.05.002

Kucia, M., Jankowski, K., Reca, R., Wysoczynski, M., Bandura, L., Allendorf, D. J., et al. (2004). CXCR4-SDF-1 signalling, locomotion, chemotaxis and adhesion. J. Mol. Histol. 35, 233-245. doi: 10.1023/B:HIJO.0000032355.66 152.b8

Kujala, K., Paavola, J., Lahti, A., Larsson, K., Pekkanen-Mattila, M., Viitasalo, M., et al. (2012). Cell model of catecholaminergic polymorphic ventricular tachycardia reveals early and delayed afterdepolarizations. PLoS ONE 7:e44660. doi: 10.1371/journal.pone.0044660

Lacolley, P., Regnault, V., Nicoletti, A., Li, Z., and Michel, J. B. (2012). The vascular smooth muscle cell in arterial pathology: a cell that can take on multiple roles. Cardiovasc. Res. 95, 194-204. doi: 10.1093/cvr/cvs135

Laflamme, M. A., Chen, K. Y., Naumova, A. V., Muskheli, V., Fugate, J. A., Dupras, S. K., et al. (2007). Cardiomyocytes derived from human embryonic stem cells in pro-survival factors enhance function of infarcted rat hearts. Nat. Biotechnol. 25, 1015-1024. doi: 10.1038/nbt1327

Lan, F., Lee, A. S., Liang, P., Sanchez-Freire, V., Nguyen, P. K., Wang, L., et al. (2013). Abnormal calcium handling properties underlie familial hypertrophic cardiomyopathy pathology in patient-specific induced pluripotent stem cells. Cell Stem Cell 12, 101-113. doi: 10.1016/j.stem.2012.10.010

Layden, B. T., Newman, M., Chen, F., Fisher, A., and Lowe, W. L. Jr. (2010). G protein coupled receptors in embryonic stem cells: a role for Gs-alpha signaling. PLoS ONE 5:e9105. doi: 10.1371/journal.pone.0009105

Lee, D. K., Cheng, R., Nguyen, T., Fan, T., Kariyawasam, A. P., Liu, Y., et al. (2000). Characterization of apelin, the ligand for the APJ receptor. J. Neurochem. 74, 34-41. doi: 10.1046/j.1471-4159.2000.0740034.x

Lee, T. H., Song, S. H., Kim, K. L., Yi, J. Y., Shin, G. H., Kim, J. Y., et al. (2010a). Functional recapitulation of smooth muscle cells via induced pluripotent stem cells from human aortic smooth muscle cells. Circ. Res. 106, 120-128. doi: 10.1161/CIRCRESAHA.109.207902

Lee, Y. K., Ng, K. M., Chan, Y. C., Lai, W. H., Au, K. W., Ho, C. Y., et al. (2010b). Triiodothyronine promotes cardiac differentiation and maturation of embryonic stem cells via the classical genomic pathway. Mol. Endocrinol. 24, 1728-1736. doi: 10.1210/me.2010-0032

Lerman, A., and Zeiher, A. M. (2005). Endothelial function: cardiac events. Circulation 111, 363-368. doi: 10.1161/01.CIR.0000153339.27064.14

Lesman, A., Gepstein, L., and Levenberg, S. (2010). Vascularization shaping the heart. Ann. N.Y. Acad. Sci. 1188, 46-51. doi: 10.1111/j.1749-6632.2009.05082.x

Li, J., Ning, Y., Hedley, W., Saunders, B., Chen, Y., Tindill, N., et al. (2002). The molecule pages database. Nature 420, 716-717. doi: 10.1038/nature01307

Li, W., Zhou, H., Abujarour, R., Zhu, S., Young, J. J., Lin, T., et al. (2009). Generation of human-induced pluripotent stem cells in the absence of exogenous Sox2. Stem Cells 27, 2992-3000. doi: 10.1002/stem.240 
Li, Y., Zhang, Q., Yin, X., Yang, W., Du, Y., Hou, P., et al. (2011). Generation of iPSCs from mouse fibroblasts with a single gene, Oct4, and small molecules. Cell Res. 21, 196-204. doi: 10.1038/cr.2010.142

Lian, X., Bao, X., Al-Ahmad, A., Liu, J., Wu, Y., Dong, W., et al. (2014). Efficient differentiation of human pluripotent stem cells to endothelial progenitors via small-molecule activation of WNT signaling. Stem Cell Reports 3, 804-816. doi: 10.1016/j.stemcr.2014.09.005

Lian, X., Hsiao, C., Wilson, G., Zhu, K., Hazeltine, L. B., Azarin, S. M., et al. (2012). Robust cardiomyocyte differentiation from human pluripotent stem cells via temporal modulation of canonical Wnt signaling. Proc. Natl. Acad. Sci. U.S.A. 109, E1848-E1857. doi: 10.1073/pnas.1200250109

Lieu, D. K., Fu, J. D., Chiamvimonvat, N., Tung, K. C., McNerney, G. P., Huser, T., et al. (2013). Mechanism-based facilitated maturation of human pluripotent stem cell-derived cardiomyocytes. Circ. Arrhythm. Electrophysiol. 6, 191-201. doi: 10.1161/CIRCEP.111.973420

Liggett, S. B., Tepe, N. M., Lorenz, J. N., Canning, A. M., Jantz, T. D., Mitarai, S., et al. (2000). Early and delayed consequences of beta(2)-adrenergic receptor overexpression in mouse hearts: critical role for expression level. Circulation 101, 1707-1714. doi: 10.1161/01.CIR.101.14.1707

Lin, B., Li, Y., Han, L., Kaplan, A. D., Ao, Y., Kalra, S., et al. (2015). Modeling and studying mechanism of dilated cardiomyopathy using induced pluripotent stem cells derived from Duchenne Muscular Dystrophy (DMD) patients. Dis. Model. Mech. 8, 457-466. doi: 10.1242/dmm.019505

Lin, F., Owens, W. A., Chen, S., Stevens, M. E., Kesteven, S., Arthur, J. F., et al. (2001). Targeted alpha(1A)-adrenergic receptor overexpression induces enhanced cardiac contractility but not hypertrophy. Circ. Res. 89, 343-350. doi: 10.1161/hh1601.095912

Lippmann, E. S., Azarin, S. M., Kay, J. E., Nessler, R. A., Wilson, H. K., Al-Ahmad, A., et al. (2012). Derivation of blood-brain barrier endothelial cells from human pluripotent stem cells. Nat. Biotechnol. 30, 783-791. doi: 10.1038/nbt.2247

Liu, Y., Wada, R., Yamashita, T., Mi, Y., Deng, C. X., Hobson, J. P., et al. (2000). Edg-1, the G protein-coupled receptor for sphingosine-1-phosphate, is essential for vascular maturation. J. Clin. Invest. 106, 951-961. doi: 10.1172/JCI10905

Luxán, G., Casanova, J. C., Martínez-Poveda, B., Prados, B., D’Amato, G., MacGrogan, D., et al. (2013). Mutations in the NOTCH pathway regulator MIB1 cause left ventricular noncompaction cardiomyopathy. Nat. Med. 19, 193-201. doi: 10.1038/nm.3046

Lyssiotis, C. A., Foreman, R. K., Staerk, J., Garcia, M., Mathur, D., Markoulaki, S., et al. (2009). Reprogramming of murine fibroblasts to induced pluripotent stem cells with chemical complementation of Klf4. Proc. Natl. Acad. Sci. U.S.A. 106, 8912-8917. doi: 10.1073/pnas.0903860106

Macfarlane, S. R., Seatter, M. J., Kanke, T., Hunter, G. D., and Plevin, R. (2001). Proteinase-activated receptors. Pharmacol. Rev. 53, 245-282.

Marson, A., Foreman, R., Chevalier, B., Bilodeau, S., Kahn, M., Young, R. A., et al. (2008). Wnt signaling promotes reprogramming of somatic cells to pluripotency. Cell Stem Cell 3, 132-135. doi: 10.1016/j.stem.2008.06.019

Matsa, E., Rajamohan, D., Dick, E., Young, L., Mellor, I., Staniforth, A., et al. (2011). Drug evaluation in cardiomyocytes derived from human induced pluripotent stem cells carrying a long QT syndrome type 2 mutation. Eur. Heart J. 32, 952-962. doi: 10.1093/eurheartj/ehr073

McGrath, K. E., Koniski, A. D., Maltby, K. M., McGann, J. K., and Palis, J. (1999). Embryonic expression and function of the chemokine SDF-1 and its receptor, CXCR4. Dev. Biol. 213, 442-456. doi: 10.1006/dbio.1999.9405

McMurray, J. J., Adamopoulos, S., Anker, S. D., Auricchio, A., Bohm, M., Dickstein, K., et al. (2012). ESC Guidelines for the diagnosis and treatment of acute and chronic heart failure 2012: the task force for the diagnosis and treatment of acute and chronic heart failure 2012 of the european society of cardiology. Developed in collaboration with the Heart Failure Association (HFA) of the ESC. Eur. Heart J. 33, 1787-1847. doi: 10.1093/eurheartj/ ehs104

Melchior, K., Weiss, J., Zaehres, H., Kim, Y. M., Lutzko, C., Roosta, N., et al. (2008). The WNT receptor FZD7 contributes to self-renewal signaling of human embryonic stem cells. Biol. Chem. 389, 897-903. doi: 10.1515/BC.2008.108

Mercola, M., Colas, A., and Willems, E. (2013). Induced pluripotent stem cells in cardiovascular drug discovery. Circ. Res. 112, 534-548. doi: 10.1161/CIRCRESAHA.111.250266

Michiels, C. (2003). Endothelial cell functions. J. Cell. Physiol. 196, 430-443. doi: $10.1002 /$ jcp. 10333
Miller, R. J., Banisadr, G., and Bhattacharyya, B. J. (2008). CXCR4 signaling in the regulation of stem cell migration and development. J. Neuroimmunol. 198, 31-38. doi: 10.1016/j.jneuroim.2008.04.008

Minami, I., Yamada, K., Otsuji, T. G., Yamamoto, T., Shen, Y., Otsuka, S., et al. (2012). A small molecule that promotes cardiac differentiation of human pluripotent stem cells under defined, cytokine- and xeno-free conditions. Cell Rep. 2, 1448-1460. doi: 10.1016/j.celrep.2012.09.015

Mioulane, M., Foldes, G., Ali, N. N., Schneider, M. D., and Harding, S. E. (2012). Development of high content imaging methods for cell death detection in human pluripotent stem cell-derived cardiomyocytes. J. Cardiovasc. Transl. Res. 5, 593-604. doi: 10.1007/s12265-012-9396-1

Moniotte, S., Kobzik, L., Feron, O., Trochu, J. N., Gauthier, C., and Balligand, J. L. (2001). Upregulation of beta(3)-adrenoceptors and altered contractile response to inotropic amines in human failing myocardium. Circulation 103, 1649-1655. doi: 10.1161/01.CIR.103.12.1649

Nakamura, K., Salomonis, N., Tomoda, K., Yamanaka, S., and Conklin, B. R. (2009). G(i)-coupled GPCR signaling controls the formation and organization of human pluripotent colonies. PLOS ONE 4:e7780. doi: 10.1371/journal.pone.0007780

Nichols, A. S., Floyd, D. H., Bruinsma, S. P., Narzinski, K., and Baranski, T. J. (2013). Frizzled receptors signal through G proteins. Cell Signal. 25, 1468-1475. doi: 10.1016/j.cellsig.2013.03.009

Novak, A., Barad, L., Zeevi-Levin, N., Shick, R., Shtrichman, R., Lorber, A., et al. (2012). Cardiomyocytes generated from CPVTD307H patients are arrhythmogenic in response to beta-adrenergic stimulation. J. Cell. Mol. Med. 16, 468-482. doi: 10.1111/j.1582-4934.2011.01476.x

Oerlemans, M. I., Goumans, M. J., van Middelaar, B., Clevers, H., Doevendans, P. A., and Sluijter, J. P. (2010). Active Wnt signaling in response to cardiac injury. Basic Res. Cardiol. 105, 631-641. doi: 10.1007/s00395-010-0100-9

Oka, T., Xu, J., and Molkentin, J. D. (2007). Re-employment of developmental transcription factors in adult heart disease. Semin. Cell Dev. Biol. 18, 117-131. doi: 10.1016/j.semcdb.2006.11.012

Paradis, P., Dali-Youcef, N., Paradis, F. W., Thibault, G., and Nemer, M. (2000). Overexpression of angiotensin II type I receptor in cardiomyocytes induces cardiac hypertrophy and remodeling. Proc. Natl. Acad. Sci. U.S.A. 97, 931-936. doi: 10.1073/pnas.97.2.931

Patterson, C., Stouffer, G. A., Madamanchi, N., and Runge, M. S. (2001). New tricks for old dogs: nonthrombotic effects of thrombin in vessel wall biology. Circ. Res. 88, 987-997. doi: 10.1161/hh1001.091447

Pauli, A., Norris, M. L., Valen, E., Chew, G. L., Gagnon, J. A., Zimmerman, S., et al. (2014). Toddler: an embryonic signal that promotes cell movement via Apelin receptors. Science 343:1248636. doi: 10.1126/science.1248636

Pébay, A., Wong, R. C., Pitson, S. M., Wolvetang, E. J., Peh, G. S., Filipczyk, A., et al. (2005). Essential roles of sphingosine-1-phosphate and platelet-derived growth factor in the maintenance of human embryonic stem cells. Stem Cells 23, 1541-1548. doi: 10.1634/stemcells.2004-0338

Pueyo, M. E., and Michel, J. B. (1997). Angiotensin II receptors in endothelial cells. Gen. Pharmacol. 29, 691-696. doi: 10.1016/S0306-3623(97)00021-9

Rao, C., Prodromakis, T., Kolker, L., Chaudhry, U. A., Trantidou, T., Sridhar, A., et al. (2013). The effect of microgrooved culture substrates on calcium cycling of cardiac myocytes derived from human induced pluripotent stem cells. Biomaterials 34, 2399-2411. doi: 10.1016/j.biomaterials.2012. 11.055

Reed, D. M., Foldes, G., Gatheral, T., Paschalaki, K. E., Lendvai, Z., Bagyura, Z., et al. (2014). Pathogen sensing pathways in human embryonic stem cell derived-endothelial cells: role of NOD1 receptors. PLOS ONE 9:e91119. doi: 10.1371/journal.pone.0091119

Ribeiro, M. C., Tertoolen, L. G., Guadix, J. A., Bellin, M., Kosmidis, G., D'Aniello, C., et al. (2015). Functional maturation of human pluripotent stem cell derived cardiomyocytes in vitro - Correlation between contraction force and electrophysiology. Biomaterials 51, 138-150. doi: 10.1016/j.biomaterials.2015.01.067

Richard, D. E., Vouret-Craviari, V., and Pouysségur, J. (2001). Angiogenesis and Gprotein-coupled receptors: signals that bridge the gap. Oncogene 20, 1556-1562. doi: 10.1038/sj.onc.1204193

Rockman, H. A., Koch, W. J., and Lefkowitz, R. J. (2002). Seven-transmembranespanning receptors and heart function. Nature 415, 206-212. doi: $10.1038 / 415206 \mathrm{a}$ 
Rogg, H., de Gasparo, M., Graedel, E., Stulz, P., Burkart, F., Eberhard, M., et al. (1996). Angiotensin II-receptor subtypes in human atria and evidence for alterations in patients with cardiac dysfunction. Eur. Heart J. 17, 1112-1120. doi: 10.1093/oxfordjournals.eurheartj.a015008

Rohrer, D. K., Desai, K. H., Jasper, J. R., Stevens, M. E., Regula, D. P. Jr., Barsh, G. S., et al. (1996). Targeted disruption of the mouse betal-adrenergic receptor gene: developmental and cardiovascular effects. Proc. Natl. Acad. Sci. U.S.A. 93, 7375-7380. doi: 10.1073/pnas.93.14.7375

Rokosh, D. G., Stewart, A. F., Chang, K. C., Bailey, B. A., Karliner, J. S., Camacho, S. A., et al. (1996). Alphal-adrenergic receptor subtype mRNAs are differentially regulated by alpha1-adrenergic and other hypertrophic stimuli in cardiac myocytes in culture and in vivo. Repression of alpha1B and alpha1D but induction of alpha1C. J. Biol. Chem. 271, 5839-5843. doi: $10.1074 / \mathrm{jbc} .271 .10 .5839$

Ruppel, K. M., Willison, D., Kataoka, H., Wang, A., Zheng, Y. W., Cornelissen, I., et al. (2005). Essential role for Galphal3 in endothelial cells during embryonic development. Proc. Natl. Acad. Sci. U.S.A. 102, 8281-8286. doi: 10.1073/pnas.0503326102

Salazar, N. C., Chen, J., and Rockman, H. A. (2007). Cardiac GPCRs: GPCR signaling in healthy and failing hearts. Biochim. Biophys. Acta 1768, 1006-1018. doi: 10.1016/j.bbamem.2007.02.010

Sambrano, G. R., Weiss, E. J., Zheng, Y. W., Huang, W., and Coughlin, S. R. (2001). Role of thrombin signalling in platelets in haemostasis and thrombosis. Nature 413, 74-78. doi: $10.1038 / 35092573$

Sato, N., Meijer, L., Skaltsounis, L., Greengard, P., and Brivanlou, A. H. (2004). Maintenance of pluripotency in human and mouse embryonic stem cells through activation of Wnt signaling by a pharmacological GSK-3-specific inhibitor. Nat. Med. 10, 55-63. doi: 10.1038/nm979

Schaaf, S., Shibamiya, A., Mewe, M., Eder, A., Stöhr, A., Hirt, M. N., et al. (2011). Human engineered heart tissue as a versatile tool in basic research and preclinical toxicology. PLoS ONE 6:e26397. doi: 10.1371/journal.pone.00 26397

Schulte, G., and Bryja, V. (2007). The Frizzled family of unconventional G-protein-coupled receptors. Trends Pharmacol. Sci. 28, 518-525. doi: 10.1016/j.tips.2007.09.001

Scott, I. C., Masri, B., D’Amico, L. A., Jin, S. W., Jungblut, B., Wehman, A. M., et al. (2007). The g protein-coupled receptor agtrllb regulates early development of myocardial progenitors. Dev. Cell 12, 403-413. doi: 10.1016/j.devcel.2007.01.012

Simons, M., Alitalo, K., Annex, B. H., Augustin, H. G., Beam, C., Berk, B. C., et al. (2015). State-of-the-art methods for evaluation of angiogenesis and tissue vascularization: a scientific statement from the american heart association. Circ. Res. 116, e99-e132. doi: 10.1161/res.0000000000000054

Sinha, S., Iyer, D., and Granata, A. (2014). Embryonic origins of human vascular smooth muscle cells: implications for in vitro modeling and clinical application. Cell Mol. Life Sci. 71, 2271-2288. doi: 10.1007/s00018-0131554-3

Small, K. M., Wagoner, L. E., Levin, A. M., Kardia, S. L., and Liggett, S. B. (2002). Synergistic polymorphisms of beta1- and alpha2C-adrenergic receptors and the risk of congestive heart failure. N. Engl. J. Med. 347, 1135-1142. doi: 10.1056/NEJMoa020803

Sokol, S. Y. (2011). Maintaining embryonic stem cell pluripotency with Wnt signaling. Development 138, 4341-4350. doi: 10.1242/dev.066209

Song, L., Awari, D. W., Han, E. Y., Uche-Anya, E., Park, S. H., Yabe, Y. A., et al. (2015). Dual optical recordings for action potentials and calcium handling in induced pluripotent stem cell models of cardiac arrhythmias using genetically encoded fluorescent indicators. Stem Cells Transl. Med. 4, 468-475. doi: $10.5966 / \mathrm{sctm} .2014-0245$

Soriano, P. (1999). Generalized lacZ expression with the ROSA26 Cre reporter strain. Nat. Genet. 21, 70-71. doi: 10.1038/5007

Stoehr, A., Neuber, C., Baldauf, C., Vollert, I., Friedrich, F. W., Flenner, F., et al. (2014). Automated analysis of contractile force and Ca2+ transients in engineered heart tissue. Am. J. Physiol. Heart Circ. Physiol. 306, H1353-H1363. doi: 10.1152/ajpheart.00705.2013

Sun, N., Yazawa, M., Liu, J., Han, L., Sanchez-Freire, V., Abilez, O. J., et al. (2012). Patient-specific induced pluripotent stem cells as a model for familial dilated cardiomyopathy. Sci. Transl. Med. 4, 130ra47. doi: 10.1126/scitranslmed.3003552
Suzuki, J., Matsubara, H., Urakami, M., and Inada, M. (1993). Rat angiotensin II (type 1A) receptor mRNA regulation and subtype expression in myocardial growth and hypertrophy. Circ. Res. 73, 439-447. doi: 10.1161/01.res.73.3.439

Szeto, W., Jiang, W., Tice, D. A., Rubinfeld, B., Hollingshead, P. G., Fong, S. E., et al. (2001). Overexpression of the retinoic acid-responsive gene Stra6 in human cancers and its synergistic induction by Wnt-1 and retinoic acid. Cancer Res. 61, 4197-4205.

Szokodi, I., Tavi, P., Földes, G., Voutilainen-Myllylä, S., Ilves, M., Tokola, H., et al. (2002). Apelin, the novel endogenous ligand of the orphan receptor APJ, regulates cardiac contractility. Circ. Res. 91, 434-440. doi: 10.1161/01.res.0000033522.37861.69

Tachibana, K., Hirota, S., Iizasa, H., Yoshida, H., Kawabata, K., Kataoka, Y., et al. (1998). The chemokine receptor CXCR4 is essential for vascularization of the gastrointestinal tract. Nature 393, 591-594. doi: 10.1038/31261

Tallawi, M., Rai, R., Boccaccini, A. R., and Aifantis, K. E. (2015). Effect of substrate mechanics on cardiomyocyte maturation and growth. Tissue Eng. Part B Rev. 21, 157-165. doi: 10.1089/ten.teb.2014.0383

Tanaka, A., Yuasa, S., Mearini, G., Egashira, T., Seki, T., Kodaira, M., et al. (2014). Endothelin-1 induces myofibrillar disarray and contractile vector variability in hypertrophic cardiomyopathy-induced pluripotent stem cell-derived cardiomyocytes. J. Am. Heart Assoc. 3:e001263. doi: 10.1161/JAHA.114.0 01263

Tang, C. M., and Insel, P. A. (2004). GPCR expression in the heart; "new" receptors in myocytes and fibroblasts. Trends Cardiovasc. Med. 14, 94-99. doi: 10.1016/j.tcm.2003.12.007

Tatemoto, K., Hosoya, M., Habata, Y., Fujii, R., Kakegawa, T., Zou, M. X., et al. (1998). Isolation and characterization of a novel endogenous peptide ligand for the human APJ receptor. Biochem. Biophys. Res. Commun. 251, 471-476. doi: 10.1006/bbrc.1998.9489

Tatsumi, R., Suzuki, Y., Sumi, T., Sone, M., Suemori, H., and Nakatsuji, N. (2011). Simple and highly efficient method for production of endothelial cells from human embryonic stem cells. Cell Transplant. 20, 1423-1430. doi: 10.3727/096368910X547444

Touyz, R. M., and Schiffrin, E. L. (2000). Signal transduction mechanisms mediating the physiological and pathophysiological actions of angiotensin II in vascular smooth muscle cells. Pharmacol. Rev. 52, 639-672.

Tseng, A. S., Engel, F. B., and Keating, M. T. (2006). The GSK-3 inhibitor BIO promotes proliferation in mammalian cardiomyocytes. Chem. Biol. 13, 957-963. doi: 10.1016/j.chembiol.2006.08.004

Tuteja, N. (2009). Signaling through G protein coupled receptors. Plant Signal. Behav. 4, 942-947. doi: 10.4161/psb.4.10.9530

Vodyanik, M. A., Yu, J., Zhang, X., Tian, S., Stewart, R., Thomson, J. A., et al. (2010). A mesoderm-derived precursor for mesenchymal stem and endothelial cells. Cell Stem Cell 7, 718-729. doi: 10.1016/j.stem.2010.11.011

Walsh, J., and Andrews, P. W. (2003). Expression of Wnt and Notch pathway genes in a pluripotent human embryonal carcinoma cell line and embryonic stem cell. APMIS 111, 197-210. doi: 10.1034/j.1600-0463.2003.1110124.x

Wang, G., McCain, M. L., Yang, L., He, A., Pasqualini, F. S., Agarwal, A., et al. (2014). Modeling the mitochondrial cardiomyopathy of Barth syndrome with induced pluripotent stem cell and heart-on-chip technologies. Nat. Med. 20, 616-623. doi: $10.1038 / \mathrm{nm} .3545$

Wang, I. N., Wang, X., Ge, X., Anderson, J., Ho, M., Ashley, E., et al. (2012). Apelin enhances directed cardiac differentiation of mouse and human embryonic stem cells. PLoS ONE 7:e38328. doi: 10.1371/journal.pone.0038328

Wang, Z., Yu, D., Wang, M., Wang, Q., Kouznetsova, J., Yang, R., et al. (2015). Elabela-apelin receptor signaling pathway is functional in mammalian systems. Sci. Rep. 5:8170. doi: 10.1038/srep08170

Wanjare, M., Kuo, F., and Gerecht, S. (2013). Derivation and maturation of synthetic and contractile vascular smooth muscle cells from human pluripotent stem cells. Cardiovasc. Res. 97, 321-330. doi: 10.1093/cvr/cvs315

Watabe, T., and Miyazono, K. (2009). Roles of TGF-beta family signaling in stem cell renewal and differentiation. Cell Res. 19, 103-115. doi: 10.1038/cr.2008.323

Windh, R. T., Lee, M. J., Hla, T., An, S., Barr, A. J., and Manning, D. R. (1999). Differential coupling of the sphingosine 1-phosphate receptors Edg-1, Edg3, and $\mathrm{H} 218 / \mathrm{Edg}-5$ to the $\mathrm{G}(\mathrm{i}), \mathrm{G}(\mathrm{q})$, and $\mathrm{G}(12)$ families of heterotrimeric $\mathrm{G}$ proteins. J. Biol. Chem. 274, 27351-27358. doi: 10.1074/jbc.274.39.27351

Woll, P. S., Morris, J. K., Painschab, M. S., Marcus, R. K., Kohn, A. D., Biechele, T. L., et al. (2008). Wnt signaling promotes hematoendothelial cell development 
from human embryonic stem cells. Blood 111, 122-131. doi: 10.1182/blood2007-04-084186

Wollert, K. C., and Drexler, H. (1999). The renin-angiotensin system and experimental heart failure. Cardiovasc. Res. 43, 838-849. doi: 10.1016/S00086363(99)00145-5

Wong, R. C., Tellis, I., Jamshidi, P., Pera, M., and Pébay, A. (2007). Anti-apoptotic effect of sphingosine-1-phosphate and platelet-derived growth factor in human embryonic stem cells. Stem Cells Dev. 16, 989-1001. doi: 10.1089/scd.2007.0057

Woo, A. Y., and Xiao, R. P. (2012). beta-Adrenergic receptor subtype signaling in heart: from bench to bedside. Acta Pharmacol. Sin. 33, 335-341. doi: 10.1038/aps.2011.201

Wu, H., Lee, J., Vincent, L. G., Wang, Q., Gu, M., Lan, F., et al. (2015). Epigenetic regulation of phosphodiesterases $2 \mathrm{~A}$ and $3 \mathrm{~A}$ underlies compromised betaadrenergic signaling in an iPSC model of dilated cardiomyopathy. Cell Stem Cell 17, 89-100. doi: 10.1016/j.stem.2015.04.020

Wu, L., Jia, Z., Yan, L., Wang, W., Wang, J., Zhang, Y., et al. (2013). Angiotensin II promotes cardiac differentiation of embryonic stem cells via angiotensin type 1 receptor. Differentiation 86, 23-29. doi: 10.1016/j.diff.2013.06.007

Wu, S. C., and O'Connell, T. D. (2015). Nuclear compartmentalization of alpha1-adrenergic receptor signaling in adult cardiac myocytes. J. Cardiovasc. Pharmacol. 65, 91-100. doi: 10.1097/FJC.0000000000000165

Xiang, Y., and Kobilka, B. K. (2003). Myocyte adrenoceptor signaling pathways. Science 300, 1530-1532. doi: 10.1126/science. 1079206

Xiao, R. P., Ji, X., and Lakatta, E. G. (1995). Functional coupling of the beta 2adrenoceptor to a pertussis toxin-sensitive $\mathrm{G}$ protein in cardiac myocytes. Mol. Pharmacol. 47, 322-329.

$\mathrm{Xu}$, C. (2012). Differentiation and enrichment of cardiomyocytes from human pluripotent stem cells. J. Mol. Cell. Cardiol. 52, 1203-1212. doi: 10.1016/j.yjmcc.2012.03.012

Xu, C., Police, S., Rao, N., and Carpenter, M. K. (2002). Characterization and enrichment of cardiomyocytes derived from human embryonic stem cells. Circ. Res. 91, 501-508. doi: 10.1161/01.res.0000035254.80718.91

Yan, L., Jia, Z., Cui, J., Yang, H., Yang, H., Zhang, Y., et al. (2011). Beta-adrenergic signals regulate cardiac differentiation of mouse embryonic stem cells via mitogen-activated protein kinase pathways. Dev. Growth Differ. 53, 772-779. doi: 10.1111/j.1440-169X.2011.01284.x

Yang, L., Soonpaa, M. H., Adler, E. D., Roepke, T. K., Kattman, S. J., Kennedy, M., et al. (2008). Human cardiovascular progenitor cells develop from a KDR+ embryonic-stem-cell-derived population. Nature 453, 524-528. doi: 10.1038/nature 06894

Yang, X., Rodriguez, M., Pabon, L., Fischer, K. A., Reinecke, H., Regnier, M., et al. (2014). Tri-iodo-l-thyronine promotes the maturation of human cardiomyocytes-derived from induced pluripotent stem cells. J. Mol. Cell. Cardiol. 72, 296-304. doi: 10.1016/j.yjmcc.2014.04.005
Yazawa, M., Hsueh, B., Jia, X., Pasca, A. M., Bernstein, J. A., Hallmayer, J., et al. (2011). Using induced pluripotent stem cells to investigate cardiac phenotypes in Timothy syndrome. Nature 471, 230-234. doi: 10.1038/nature09855

Yu, J., Huang, N. F., Wilson, K. D., Velotta, J. B., Huang, M., Li, Z., et al. (2009). nAChRs mediate human embryonic stem cell-derived endothelial cells: proliferation, apoptosis, and angiogenesis. PLOS ONE 4:e7040. doi: 10.1371/journal.pone.0007040

Zambidis, E. T., Park, T. S., Yu, W., Tam, A., Levine, M., Yuan, X., et al. (2008). Expression of angiotensin-converting enzyme (CD143) identifies and regulates primitive hemangioblasts derived from human pluripotent stem cells. Blood 112, 3601-3614. doi: 10.1182/blood-2008-03-144766

Zeng, X. X., Wilm, T. P., Sepich, D. S., and Solnica-Krezel, L. (2007). Apelin and its receptor control heart field formation during zebrafish gastrulation. Dev. Cell 12, 391-402. doi: 10.1016/j.devcel.2007.01.011

Zhang, J., Lian, Q., Zhu, G., Zhou, F., Sui, L., Tan, C., et al. (2011). A human iPSC model of Hutchinson Gilford Progeria reveals vascular smooth muscle and mesenchymal stem cell defects. Cell Stem Cell 8, 31-45. doi: 10.1016/j.stem.2010.12.002

Zhang, J., Wilson, G. F., Soerens, A. G., Koonce, C. H., Yu, J., Palecek, S. P., et al. (2009). Functional cardiomyocytes derived from human induced pluripotent stem cells. Circ. Res. 104, e30-e41. doi: 10.1161/circresaha.108.192237

Zhang, X. H., Haviland, S., Wei, H., Saric, T., Fatima, A., Hescheler, J., et al. (2013). Ca2+ signaling in human induced pluripotent stem cell-derived cardiomyocytes (iPS-CM) from normal and catecholaminergic polymorphic ventricular tachycardia (CPVT)-afflicted subjects. Cell Calcium 54, 57-70. doi: 10.1016/j.ceca.2013.04.004

Zhi, D., Irvin, M. R., Gu, C. C., Stoddard, A. J., Lorier, R., Matter, A., et al. (2012). Whole-exome sequencing and an iPSC-derived cardiomyocyte model provides a powerful platform for gene discovery in left ventricular hypertrophy. Front. Genet. 3:92. doi: 10.3389/fgene.2012.00092

Zhong, H., and Minneman, K. P. (1999). Alpha1-adrenoceptor subtypes. Eur. J. Pharmacol. 375, 261-276. doi: 10.1016/S0014-2999(99)00222-8

Conflict of Interest Statement: The authors declare that the research was conducted in the absence of any commercial or financial relationships that could be construed as a potential conflict of interest.

Copyright () 2015 Dolatshad, Hellen, Jabbour, Harding and Földes. This is an openaccess article distributed under the terms of the Creative Commons Attribution License (CC BY). The use, distribution or reproduction in other forums is permitted, provided the original author(s) or licensor are credited and that the original publication in this journal is cited, in accordance with accepted academic practice. No use, distribution or reproduction is permitted which does not comply with these terms. 